EUROPEAN CENTRAL BANK

WORKING PAPER SERIES

N0. 328 / APRIL 2004

\title{
NON-FUNDAMENTAL EXCHANGE RATE VOLATILITY AND WELFARE
}

by Roland Straub and Ivan Tchakarov

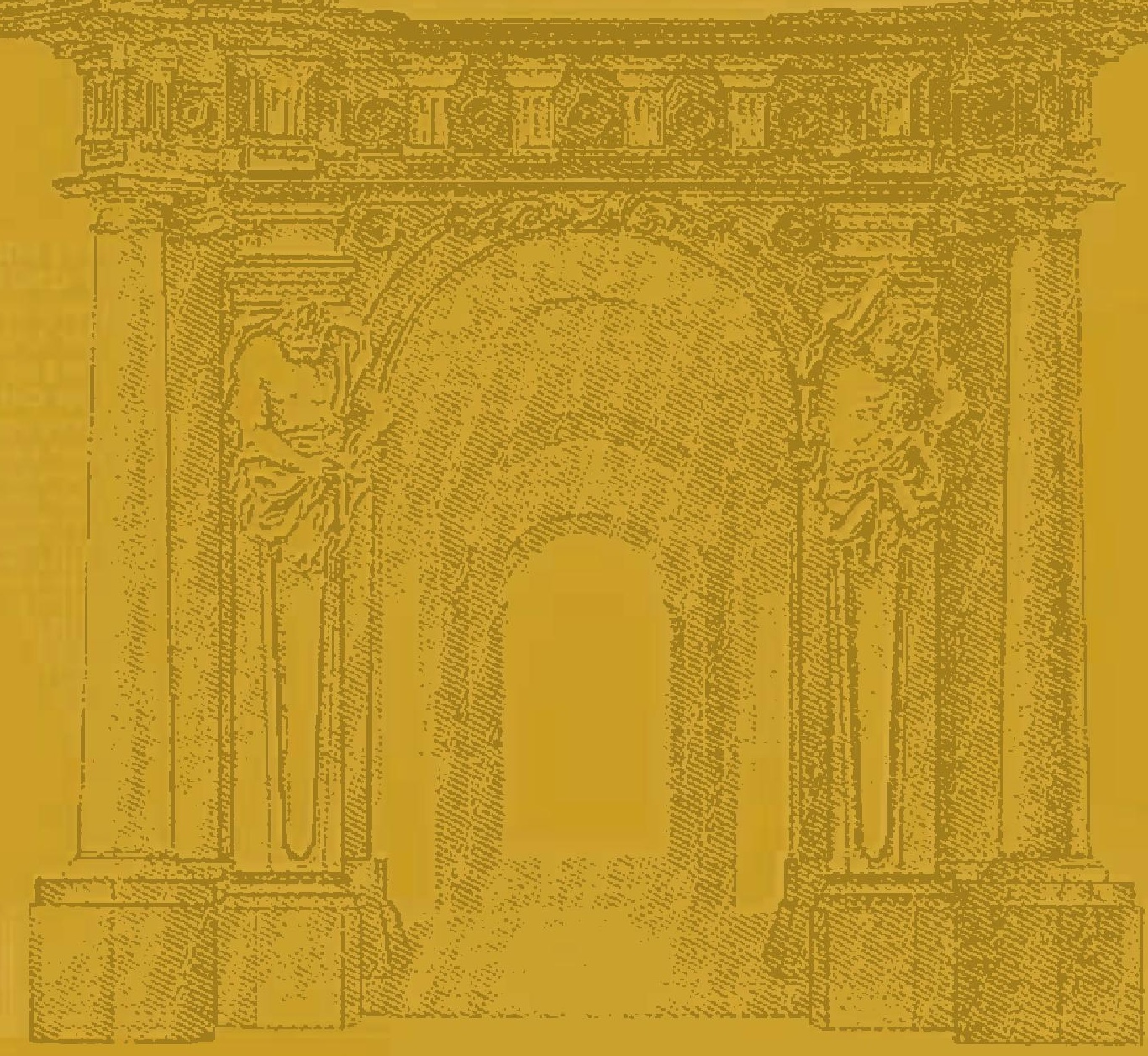




\title{
WORKING PAPER SERIES
}

N0. 328 / APRIL 2004

\section{NON-FUNDAMENTAL EXCHANGE RATE VOLATILITY AND WELFARE'}

\author{
by Roland Straub ${ }^{2}$
} and Ivan Tchakarov ${ }^{3}$

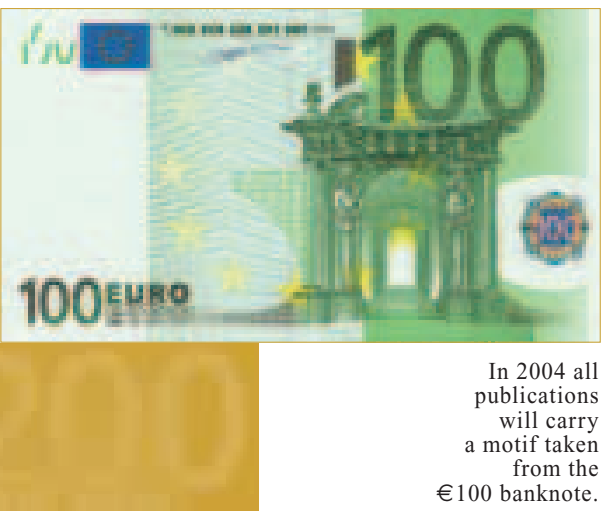

This paper can be downloaded without charge from http://www.ecb.int or from the Social Science Research Network electronic library at http://ssrn.com/abstract_id $=526991$.

I We are indebted to Oscar Jorda for providing us with his code and very helpful comments on the GARCH-SVAR model. We are especially grateful to Paul Bergin for many useful discussions. We wish to thank Mike Artis, Anindya Banerjee, Giuseppe Bertola, Guenter Coenen, Michael Ehrmann, Igor Masten, David Vestin and seminar participants at the European Central Bank, European University Institute and National Bank of Hungary for helpful comments. We thank the ECB for hospitality. The views expressed in this paper are those of the authors and do not necessarily reflect the position of the International Monetary Fund. All remaining errors are ours. 


\section{드 European Central Bank, 2004}

\section{Address}

Kaiserstrasse 29

60311 Frankfurt am Main, Germany

Postal address

Postfach 160319

60066 Frankfurt am Main, Germany

Telephone

+496913440

\section{Internet}

http://www.ecb.int

Fax

+496913446000

Telex

411144 ecb d

All rights reserved.

Reproduction for educational and noncommercial purposes is permitted provided that the source is acknowledged.

The views expressed in this paper do not necessarily reflect those of the European Central Bank.

The statement of purpose for the ECB Working Paper Series is available from the ECB website, http://www.ecb.int.

ISSN 1561-0810 (print)

ISSN 1725-2806 (online) 


\section{CONTENTS}

Abstract 4

Non-technical summary 5

1 Introduction 7

2 Empirical analysis $\quad 10$

2.1 The GARCH-SVAR model $\quad 10$

2.2 Identifying exchange rate shocks $\quad$ I2

2.3 Empirical results $\quad$ I3

3 The model 18

3.1 Market structure 18

3.2 Home household problem 20

3.3 Home firm problem 22

3.4 Government 23

3.5 Market clearing 24

3.6 Computation of the welfare measure 25

3.7 Calibration 26

4 Results 27

4.1 Benchmark case $\quad 27$

4.2 Habit persistence 29

5 Conclusion 30

References 3I

Tables and figures $\quad 36$

European Central Bank

working paper series 


\begin{abstract}
We lay out an empirical and a theoretical model to analyze the effects of non-fundamental exchange rate volatility on economic activity and welfare. In the first part of the paper, the GARCH-SVAR model is applied to measure empirically the effect of the conditional exogenous exchange rate volatility on the conditional mean of the endogenous variables in our open economy VAR. Our results for Canada, Germany and UK indicate that the effects of exchange rate uncertainty are small empirically. In the second part, we investigate the effect of non-fundamental exchange rate volatility in a stochastic open economy model. The second order approximation method of Sims [2003] is applied to the model equilibrium conditions. We show that in a model with habit persistence, even non-fundamental exchange rate volatility that generate only small variation in the unconditional mean of the variables might induce economically significant welfare changes.
\end{abstract}

JEL Classification: C32; F31; F41;

Keywords: GARCH-SVAR; Exchange rate volatility; Second-order approximation; Welfare; 


\section{Non-technical summary}

The issue of exchange rate risk is ubiquitous in international economics, and this is best understood and exemplified by the incessant debates about the level and scope of its damaging effects. The tendency for nominal exchange rates to move so volatilely and unpredictably has been blamed for limiting gains from international trade and lowering welfare.

Interestingly, however, there is little empirical evidence that exchange rate variability has a significant impact on trade and welfare, and interest rate volatility appears to matter a lot more than exchange rates volatility for G-3 activity. Furthermore, exchange rate volatility may not necessarily be harmful. In a world with sticky prices, fluctuations of the exchange rate as a response to changes in economic fundamentals might offset the deleterious effect of idiosyncratic negative real shocks.

At the same time advocates of greater exchange rate stability across the major currencies argue that a significant part of exchange rate volatility is created in the exchange rate market itself. If exchange rate fluctuations are due to non-fundamental reasons in the sense that they are primarily driven by investor psychology, there might still exist a good case for exchange rate stability. If the exchange rate breeds its own shock then it may also be a source of welfare reduction.

The main objective of this paper is to evaluate the effects of non-fundamental exchange rate volatility on economic activity and welfare, and this question is tackled both empirically and theoretically.

The effect of exchange rate variability is investigated from an empirical point of view by applying the GARCH-SVAR methodology that, contrary to the usual linear VAR approach, allows one to measure the effect of the conditional variance of the exchange rate on the conditional means of the endogenous variables. We model non-fundamental exchange rate volatility by postulating that the fraction of volatility that can not be accounted for by a change in economic fundamentals such as output, inflation etc., is induced by non-fundamental causes. The impulse response functions to an exchange rate shock are consistent with common knowledge, but indicate that for the UK, Germany and Canada the effects of exchange rate volatility originating in the exchange rate market are very small. This seems to justify arguments about the lack of evidence concerning the role of exchange rate variability for macroeconomic aggregates.

While the approach that we employ in the empirical part is informative, 
it does not reflect a true welfare analysis. A rigorous welfare exploration requires examining not only the impulse response functions to one-time shocks, but the construction of a model and its stochastic equilibria under a particular policy regime.

To this end, the second part of the paper investigates the effects of exchange rate uncertainty in a stochastic open economy model. In order not to rely on traditional restrictive assumptions for welfare evaluations, we solve the model by applying to the equilibrium conditions the second-order approximation of Sims [2003] . We show that in a model with habit persistence, even non-fundamental exchange rate shocks that generate only small variation in the unconditional means of the variables might induce economically significant welfare changes. If we believe that the assumption of habits in the consumption is realistic, the result provides good grounds for concluding that, even though wildly gyrating exchange rates do not seem to feed back into the real economy, the welfare consequences of such small effects may be economically important.

In conclusion, we use a novel econometric methodology to provide some new evidence that empirically exchange rate volatility has small effects on the level of key macroeconomic aggregates. Some have gone to interpret such evidence as showing that exchange rates have no meaningful effect at all. We try to emphasize the point that such empirical findings should not necessarily be understood to mean that welfare is not affected in an economically significant way. 


\section{Introduction}

Rogoff [2003] has delineated a couple of reasons why the creation of a world currency and, for that matter, a close coordination of macroeconomic policies among the G3 countries is not needed. One of the fallacies leading people to believe in cooperation schemes is that "...G3 exchange rate volatility is a disaster". The main argument is that though exchange rate fluctuates widely in comparison with goods prices it is not immediately obvious that exchange rate variability has necessarily a huge deleterious effect on macro variables. Baxter and Stockman [1989] were the first to point out the difficulty in demonstrating that exchange rate volatility affects macroeconomic fundamentals. Though some research has succeeded in showing that exchange rate variability can correlate negatively with trade and direct foreign investment ${ }^{1}$, the general assessment is that the feedback to the real economy is far slower and less pronounced than a model based on the Mundell-Fleming framework would predict.

Still, proponents of exchange rate stability across countries argue that the standard theoretical and empirical analyses are misguided in that they typically do not distinguish between fundamental and non-fundamental exchange rate volatility. If the fluctuation of the exchange rate is a reaction to changes in the economic fundamentals, its effect can be even positive. In a world with sticky prices the adjustment of the nominal exchange rate can offset the deleterious effects of negative real shocks. This shock absorber quality of flexible exchange rate has been discussed already by Friedman [1953]. However, there is an ongoing discussion as to what extent the exchange breeds its own shocks and how destabilizing this shock are. Obviously the volatility that is caused directly by these shocks can be considered as non-fundamental since it is not caused through the endogenous reaction of the exchange rate to the volatility of economic fundamentals, but through the reaction to the exogenous component of the exchange rate itself. This argument is related to the work of Jeanne and Rose [2002] who develop a theoretical model of the exchange rate behavior, based on the presence of noise traders in the exchange rate market. Their model identifies the reason for the huge discrepancy between the volatility of the exchange rate and the volatility of fundamentals in the fact that the exchange rate is a shock creator itself.

Our paper also relates to the literature that compares the role of the

\footnotetext{
${ }^{1}$ See Frankel and Wei [1993] or Goldberg and Klein [1998].
} 
exchange rate as a shock creator with that of a shock absorber. A paper by Artis and Ehrmann [2000] finds that the exchange rate market is a prominent source of disturbance in UK, Denmark and Sweden. To the extent that excessive volatility in the exchange rate market can not be accounted for by the volatility of economic fundamentals, it might be desirable to speak about non-fundamental exchange rate volatility and try to address the issue of its significance for welfare.

While the question of exchange rate volatility has considerable practical implications, the attempt to analyze its welfare implications does not constitute a straightforward exercise. On the theoretical level researchers typically rely on the first order approximation of the model equilibrium conditions, i.e. they implicitly assume certainty equivalence or impose a number of simplifying assumption to permit analytical solutions ${ }^{2}$. Obviously, if volatility is believed to be an important determinant of economic behavior, exercises that explicitly do not take into account the second moments of the model might lead to misleading results. On the empirical level the structural vector autoregression, the main workhorse of empirical macroeconomics, does not allow the volatility of the shocks to have an effect on the conditional mean of the endogenous variables.

This paper applies recently developed methods to evaluate the effect of non-fundamental exchange rate volatility on welfare. The appropriate way to tackle this question theoretically is to derive a dynamic open economy model and to evaluate the effects of exchange rate uncertainty in a micro-founded welfare function in the spirit of Woodford [2003]. However the evaluation of welfare in this set up is not trivial. As Woodford emphasizes, in the case of several distortions in the model, the first order Taylor approximations to the model equilibrium make the derivation of a micro-founded social objective function a hard task. One contribution of this paper is to deal with these questions in a "quadratic-quadratic framework" that easily disposes of the above-mentioned difficulties. A quadratic approximation to a modelbased non-ad-hoc micro-founded welfare function will be evaluated with a quadratic approximation of the equilibrium conditions using the recently developed technique by Sims et.al. [2003]. The theoretical set up draws heavily on the model by Bergin and Tchakarov [2003]. However, while Bergin and Tchakarov [2003] analyze the welfare effects of exchange rate variability gen-

\footnotetext{
${ }^{2}$ See e.g. Obstfeld and Rogoff [2001], Devereux and Engel [2000] and Baccheta and Van Wincoop [2000].
} 
erated by monetary and technology shocks (as in the seminal contribution of Obstfeld and Rogoff [2001]) under flexible and fixed exchange rates, this paper focuses on the welfare effects of non-fundamental exchange rate volatility (in the spirit of Jeanne and Rose [2002]).

Empirical investigation of these issues requires that we introduce appropriate econometric methods to measure the effects of exchange rate uncertainty (which we take to mean volatility for empirical purposes) on the conditional mean of the variables in a VAR. A natural solution to this problem consists of generalizing the GARCH-M model to a multivariate context. The resulting model, called GARCH-SVAR, has been recently developed by Jorda and Salyer [2003]. In addition to the fact that it allows a direct measurement of volatility effects on the impulse response functions, it also delivers interesting new properties for them: different shapes as a function of the magnitude of the shock and asymmetric responses to positive and negative shocks. We operationalize the assumption of non-fundamental exchange rate volatility by assuming that the portion of volatility that is not explainable by economic fundamentals like output, inflation etc. is due to non-fundamental factors. Therefore, these non-fundamental shocks provide a direct connection to the theoretical model where we assume that a shock to the uncovered interest parity condition (we also refer to this as an exchange rate shock) is the main reason why economic agents might form inaccurate predictions about the exchange rate.

The basic results indicate that the impulse response functions to the identified exchange rate shock seem to coincide with the general belief that exchange rate depreciation puts inflationary pressure in the economy and brings about a contractionary monetary policy. The effects on the real economy are difficult to assess and this particular feature has also been recognized by other researchers (see for example Smets [2001]). The conditional means of the variables in the GARCH-SVAR are quite small and not statistically significant. While the empirical model delivers a nice representation of the volatility effects of the exchange rate on the conditional means, it is not particularly helpful in drawing conclusions about the possible welfare effects of exchange rate shocks.

The two-country NOEM model has the utility function as a natural criterion in evaluating the effects of non-fundamental exchange rate shocks. One finding of the theoretical model is that exchange rate shocks are more important than technology shocks in explaining exchange rate volatility, but still are not enough to deliver values of volatility observed in real data. The wel- 
fare effects of exchange rate shocks are small for the benchmark specification of the model where the utility function is time separable in consumption, but are significantly bigger for a model with habit persistence even though the effects on the level of the endogenous variables are still small. And exactly this point, our main argument, provides a straight forward relationship between the empirical and the theoretical part of the paper. Despite the fact that our empirical results show small effects of non-fundamental exchange rate volatility on the level of variables, we argue in the theoretical part that even in the case of small "observable" effects on the level of endogenous variables, non-fundamental exchange rate volatility might have a significant effect on welfare.

The paper is organized as follow. Section 2 describes the GARCH-SVAR methodology and presents results for Germany, UK and Canada. Section 3 sets up the benchmark two country open economy model and applies the Sims methodology. Section 4 presents a modification of the benchmark case by introducing habit persistence in the utility function of the representative agent. Section 5 concludes.

\section{Empirical analysis}

\subsection{The GARCH-SVAR Model}

This section presents some empirical results on the effect of exchange rate uncertainty on economic activity. Empirically, exchange rate uncertainty is best represented by modelling the conditional (i.e. time varying) volatility of a shock generated in the foreign exchange rate market. Consequently, an empirical model is applied to analyze the transmission of the non-fundamental part of the exchange rate volatility on the level of the economic activity . The recently developed GARCH-SVAR model (for a much more exhaustive discussion see Jorda and Salyer [2003]) seems to be the natural choice. The advantage of this method is that it allows the conditional variance to enter directly into the specification of the conditional mean in the commonly used vector autoregression (VAR).

The GARCH-SVAR modelled can be described by:

$$
Y A^{-1}=X \pi A^{-1}+G \beta A^{-1}+\varepsilon
$$

where $Y$ is a $(T x n)$ matrix whose rows contain the observations of the $(n x 1)$ 
vector $y_{t}^{\prime}, A$ is a $(n x n)$ the matrix of contemporaneous relationships between the endogenous variables, $X$ is a $(T x(n p+1))$ matrix that contains the constant and up to $p$ lags of $Y$. G is a $(T x(n x n x p))$ matrix of contemporaneous and lagged conditional variances $H$ of the structural shocks $\varepsilon$, while $\beta$ is the matrix of the corresponding coefficients. The conditional variance $\mathrm{H}$ is modelled by using the multivariate $\operatorname{GARCH}(r, m)$ specification. However, since the structural shocks are uncorrelated by construction the multivariate structure can be simplified into:

$$
H_{t} i=W+\Gamma_{i} H_{t-1} i+. .+\Gamma_{r} H_{t-p} i+\ldots+\Phi_{1} \varepsilon_{t-1}^{2}+\ldots+\Phi_{m} \varepsilon_{t-m}^{2}
$$

where $i$ is an $(n x 1)$ vector of ones that vectorizes the matrix $H_{t}$ into an $(n x 1)$ vector. Note that since the conditional variance is a non-linear function of the structural shock, the magnitude of the shock does matter for the shapes of the Impulse Response functions. This is in contrast to the standard SVAR specification, where the magnitude of the shock had solely a scale effect on the responses. Furthermore, since an increase in the conditional variance depends solely on the size but not on the sign of the shock, the total effect of the shock on the conditional mean is asymmetric. Given the estimates in (2), the impulse response functions for the system can be calculated as suggested in Hamilton (1994):

$$
\begin{array}{r}
\frac{\partial y_{j, t+s}}{\partial \varepsilon_{i, t}}=E\left(y_{j, t+s} \mid \varepsilon_{i, t}=\varepsilon_{i}^{*} ; y_{t-1}, H_{t}, \ldots, y_{t-p}, H_{t-p+1}\right)- \\
E\left(y_{j, t+s} \mid \varepsilon_{i, t} y_{t-1}, H_{t}, \ldots, y_{t-p}, H_{t-p+1}\right) .
\end{array}
$$

where $\varepsilon_{i, t}$ denoted the magnitude of the shock to the $i^{t h}$ structural shock being considered in the specific impulse response. Notice that a shock to the $i^{\text {th }}$ variable has the usual effect on the conditional mean of the system but it simultaneously affects the conditional variance (through the lags $\varepsilon_{t-i}^{2}$ ), thus having an additional effect on the conditional mean via the lags $H_{t-i}$. This feature provides a direct measure of the effect of time-varying uncertainty (or more generally, of second-order effects): the difference between the impulse response given in expression (3) and the impulse response resulting from setting the coefficients $\beta$ in (1) to zero. 


\subsection{Identifying exchange rate shocks}

While the identification of monetary policy shocks in closed economy is already a standard exercise within a SVAR setting (for a survey see Christiano, Eichenbaum and Evans [1999]), the proper specification of an open-economy SVAR has been found to be fraught with difficulties. While various papers have examined the effects of monetary shocks in open economies (see for example Eichenbaum and Evans [1995], Grilli and Roubini [1996], Cushman and Zha [1997], Kim [2001], Kim and Roubini [2001] and Smets [2001]), this strand of literature has been distinctly less successful in providing good explanation for empirical regularities than the SVAR approach in closed economies.

These considerations are even truer for the identification of exchange rate shocks. There are few papers that explicitly try to pin down exchange rate shocks. Artis and Ehrmann [2000] provide an analyses that tries to examine the role of the exchange rate as shock-absorber as opposed to a source of its own and destabilizing shocks. Choudhri, Faruqee and Hakura [2003] discuss the performance of various new open-economy macro models in explaining the exchange-rate pass-through in different price indexes. Smets [2001] also provides some estimates of impulse response functions to an exchange rate shock.

A common feature of open-economy SVAR models is the role of exchange rate shock in the creation and propagation of disturbances. For example, the open economy VAR as is specified in Eichenbaum and Evans [1995] contains the following variables: the log of US Industrial Production (US IP), the log of US consumer price index (US CPI), the Federal Funds rate (FFR), the log of the Industrial Production, the log of the CPI, the short term monetary policy rate and the US Dollar exchange rate of the foreign economy economy. The structural shocks are identified by using the Cholesky decomposition, following the order given above. As argued by Kim and Roubini [2001], when the goal is the identification of monetary policy shocks, this specification might lead to some "puzzles" originating mainly from the fact that this particular ordering implies that neither the US nor the foreign monetary authority react contemporaneously to exchange rate fluctuations. This is the primary reason why Smets [2001] and Kim and Roubini [2001] employ non-recursive identification schemes that allow for such influences.

While the use of Cholesky identification schemes might not be desirable in trying to identify monetary policy shocks in open economies, the identification of exchange rate shocks do not have to necessarily suffer from the same 
problems. While Artis and Ehrmann [2000] use the identification proposed by Smets [2001], Choudhri, Faruqee and Hakura [2003] employ a Cholesky decomposition. Our main goal in identifying the exchange rate shock is to produce impulse response functions that are broadly in line with common sense, i.e. depreciation leads to an increase in domestic prices and interest rate. Our preferred specification augments the one used by Eichenbaum and Evans [1995] by adding, following Kim and Roubini [2001], the log of the World Index of Oil Price after the log of US CPI ${ }^{3}$.

The estimation of the impulse response functions involves several steps. In the first step we run an OLS regression equation by equation on the $p$ lag values of the endogenous variables as in the standard VAR literature. Using the Cholesky factorization, we identify the structural shocks in the system. We test this structural shock for ARCH effect by applying the standard LM-test. Given that our test indicates ARCH effect in the residual series, we estimate the coefficient of the GARCH model by maximum likelihood as specified in (2). In the next step, we run OLS equation by equation by augmenting the standard VAR specification by the conditional volatilities as described in (1). After identifying the structural residuals of the GARCHSVAR by Cholesky factorization the GARCH model is estimated again. We iterate on the last steps until convergence.

\subsection{Empirical results}

In this section we present the results of the GARCH-SVAR model for Germany, UK and Canada. The analysis is focused on a sample of the biggest trading partners of the United States, except for Japan and Mexico ${ }^{4}$. The

\footnotetext{
${ }^{3}$ Some remarks on unit roots and cointegration. Naturally, in our non-stationary set up the question arises whether it is appropriate to run the VAR in levels. In the presence of cointegration our approach leads to overparametrization which generates consistent, but inefficient estimates. However, this loss of efficiency has to be weighted against the risk of inconsistency which occurs when the wrong restrictions are imposed. Imposing the wrong cointegrating parameters will make the system converge to the wrong longrun equilibria (see Sims, Stock and Watson (1990) for a discussion). Running the VAR in first differences generate similar problems. VAR in first differences will reduce the number of parameters that are needed to be estimated but is potentially misspecified in the presence of cointegration. We choose therefore, in line with the large literature on monetary transmission mechanism (see e.g. Kim and Roubini (2001) or Eichenbaum and Evans(1995) ), to run our VAR in levels rather than in VECM form or first differences.

${ }^{4}$ Mexico had a fixed exchange rate arrangement for part of the considered period and is therefore not suited for the empirical analysis. We did experiment with data on Japan,
} 
sample contains the post Bretton-Woods period, i.e. beginning in 1974 and ending in May 2002 for a total of 341 observations. In order to extend our German sample for the post-DM (Euro) period the Euro-US Dollar exchange rate is converted by using the fixed DM-Euro conversion rate.

For Germany, UK and Canada 8 lags are used in the VAR specification. The LM test is applied in order to detect ARCH effects in the remaining residual (see results in table 1). The results indicate significant ARCH effects in the exchange rate for Germany. The null hypothesis of no $\mathrm{ARCH}$ effect can be rejected with a p-value of 0.029 in our sample. In the next step, the conditional volatility of the exchange rate is calculated and is used as an additional explanatory variable in the VAR. The values of the calculated conditional variance are depicted in Figure 1. There are signs of significant non-fundamental volatility in the DM/USD exchange rate in the years 1981, 1985 and 1987. This is a fact that gives us confidence that the shock that we have identified as an exchange rate shock really has the characteristics of such a shock. It is well known that the DM/US exchange rate has been quite volatile in this time frame. The significant dollar appreciation in the beginning of the 80s led to the Plaza agreement from Sep. 1985. The dollar dropped sharply after this agreement and continued to decline through 1986 and early 1987. Then the Louvre meeting in Feb. 1987 followed the discontent of the European countries from the continuing dollar depreciation. In other words, a case could be made that this time period created many opportunities for speculation in the foreign exchange market and "noise trading" was abundant.

Table 1: LM-Test

\begin{tabular}{lccc} 
& Germany & United Kingdom & Canada \\
\hline \hline Constant & 0.881 & 0.823 & 0.881 \\
$\beta$ & 0.119 & 0.176 & 0.117 \\
p-value & 0.029 & 0.001 & 0.033 \\
\hline \hline
\end{tabular}

If the residual has tested positive for $\mathrm{ARCH}$ effects, we construct an initial $\operatorname{GARCH}(1,1)$ model for that residual. The GARCH model has been

but we encountered problems of convergence in the solution algorithm. 
Table 2: GARCH Estimation

\begin{tabular}{lccc} 
& Germany & United Kingdom & Canada \\
\hline \hline Constant & 0.550 & 0.087 & 0.798 \\
& $(0.035)$ & $(0.003)$ & $(0.118)$ \\
GARCH-term & 0.270 & 0.824 & 0.083 \\
& $(0.038)$ & $(0.005)$ & $(0.122)$ \\
ARCH-term & 0.189 & 0.088 & 0.117 \\
& $(0.010)$ & $(0.001)$ & $(0.006)$ \\
\hline \hline
\end{tabular}

Note: Standard errors in brackets.

chosen with only one ARCH and GARCH term since in most empirical models this specification has been shown to be enough to describe all GARCH effects. Table 2 shows the results for the GARCH estimation of the identified exchange rate shock.

Figure 2 compares the standard SVAR and GARCH-SVAR impulse response functions after a positive, one standard deviation exchange rate shock (all logged values are multiplied by hundred, so the results are presented in percentage points $)^{5}$. Despite the apparent merits of the GARCH-SVAR, we were unable to find a measurable effect of volatility on the impulse response functions. The difference between the two specifications are mostly statistically insignificant. Moreover, when we experimented by setting the conditional mean response to volatility to be zero in the GARCH-SVAR and subjecting the dynamic system to one standard deviation shock, the responses literally lied on top of each other, making them indistinguishable.

We argued above the fact that the identification of exchange rate shocks in a SVAR setting has not been an active area of interest in past research. Smets [2001] provides impulse response functions to an exchange rate shock for Germany so that his results are an obvious object for comparison. In his specification the main effect of an appreciation of the exchange rate is to move prices higher, while the effect on the interest rate and output is ambiguous. Smets [2001] concludes that his model is "misspecified". In our model monetary policy in Germany reacts as expected with a statistically significant interest rate increase after a depreciation of the Deutschemark.

\footnotetext{
${ }^{5}$ Monte Carlo simulated standard error bands for the IRFs are depicted.
} 
The depreciation of the exchange rate has a significant positive impact on the inflation for the first 2 years, but a negative (non-significant) effect after 2 years. As Grilli and Roubini [1996] emphasize, the reaction of inflation and output depends on the combination of the exchange rate shock and monetary policy (i.e. on the exchange rate pass-through and expenditure switching on one hand, and on the monetary transmission mechanism on the other hand). In Germany, the depreciation leads to an ambiguous effect on industrial production which is a very common feature of identified exchange rate shocks. All in all, we believe that our exchange rate shock for Germany does a decent job of describing the responses of prices and interest rates to shocks that come from the exchange rate market.

Even though the results from Figure 2 were quite small, we should keep in mind that the size of the shock was one standard deviation, i.e. 0.05, and, therefore, it can hardly be expected that a shock of such magnitude will cause any revisions in uncertainty. That is why in Figure 3 we experiment with a shock of 2. We choose this magnitude since from Jan. 1980 till June 1985 the DM depreciated from 1.72 to 3.06 DM per dollar and then it again appreciated to approximately 1.63 by the end of 1987 . These are the kind of fluctuations that we envision when we speak about the effects of exchange rate volatility on conditional means.

Moreover, a simple comparison of SVAR and GARCH-SVAR models is not very appropriate since, effectively, these are different models because the right hand-side variables in the GARCH-SVAR include the contemporaneous and lagged conditional variances as specified in (1). The proper way to evaluate the relative importance of exchange rate uncertainty is to compare the IRFs of the GARCH-SVAR model with and without the effect of exchange rate volatility on the conditional mean of the variables. ${ }^{6}$. First, the exchange rate equation is shocked by 2 units. In the same step the responses of the GARCH-SVAR are compared with the responses one would obtain by shutting down the $\beta$ coefficient in expression (1). This experiment delivers a direct measure of the importance of exchange rate volatility on the conditional mean of inflation and output.

The visual inspection of the IRFs delivers the following results. Although the difference between the GARCH-SVAR with volatility and without volatility effect is ambiguous at the beginning, we can clearly say that exchange

\footnotetext{
${ }^{6}$ Since the IRFs depend on the magnitude of the shock, the calculation of the the standard error bands are problematic in this set up.
} 
rate volatility leads to higher output one year after the shock. While this might seem somewhat unexpected, exchange rate uncertainty may lead to increasing economic activity which is line with the results obtained by Bachetta and Van Wincoop [2000], Dotsey and Srate [2000], Jorda and Salyer [2003], and Dupor [2003]. Moreover, it has been shown by Bachetta and Van Wincoop [2000] that exchange rate variability might also be associated with increased trade between countries. This is not inconsistent with our impulse response for output. Furthermore, uncertainty leads to a less muted response of monetary policy and lower inflationary pressure. It is important to be clear about the differences between the results depicted by our empirical model and the traditional channels of exchange rate risk developed by Obstfeld and Rogoff [2001]. In their model exchange rate uncertainty, that is generated by monetary and technology shocks, forces firms to charge higher prices for their products and this reduces output and welfare. The GARCHSVAR model shows a different picture where shocks originating purely in the exchange rate markets might lead to dissimilar results. As we will discuss later in the theoretical part, the main reason why exchange rate volatility might lead to higher output is that a rise in the variability of the exchange rate increases the average level of investments through precautionary savings and, therefore, gives rise to a higher level of production. This is associated with a fall in prices and, as expected, less activist monetary policy.

The results for UK and Canada show similar patterns. The LM test detects ARCH effects for both countries. The GARCH estimation results reported in Table 2 show that the GARCH and ARCH terms are very statistically significant for UK, whereas in the case of Canada only the coefficient on the ARCH term is significant. Figures 4 and 6 display high conditional volatility for the GBP/USD and CAND/USD exchange rates during the middle 80s. Note that around the crisis with the British pound in 1991-1992 our estimates reveal the highest conditional volatility. The impulse response functions are shown in Figures 5 and 7 and are similar to the results for Germany. A depreciation of the currency to the dollar leads generally to an increase in prices and the short-term interest rate, and ambiguous effects on industrial production. The effects of conditional volatility of the exchange rate on the conditional means are very negligible as in the case of Germany. In fact, we need very big shocks in order to be able to show a picture where the effects of conditional volatility on the means is visible. This is the reason why we do not have a counterpart of Figure 3. In any case, we should say that these second-order effects are qualitatively the same as those shown in 
Figure 3, i.e. exchange rate volatility brings about higher output and lower inflation and interest rate.

As was already emphasized, the magnitude of the effect of exchange rate risk on the variables depends very much on the size of the shock. This is obvious since bigger shocks are more likely to cause revisions in volatility. For the three countries in question the effects of exchange rate volatility are very small for one standard deviation shocks and statistically not different from zero. However, as our theoretical model will emphasize, even small changes in the level of the variables generated by a non-fundamental exchange rate shock could have economically significant effect on welfare.

\section{The Model}

In this section we develop a theoretical model that gives a quantitative handle on the effects of exchange rate variability on the means of the variables of interest. The model draws heavily on Bergin and Tchakarov [2003], augments the original exposition by introducing shocks to the uncovered interest parity (UIP) condition and is solved by the second-order accurate solution of Sims [2003].

Consider a two country world, hereafter referred to as home and foreign. Agents consume two final goods, where each country specializes in the production of one of these goods. Monopolistically competitive firms produce intermediate goods using capital and labor. Prices are sticky because of adjustment costs. The international asset market is limited to two noncontingent nominal bonds, denominated in the currencies of the home and foreign countries.

\subsection{Market structure}

Final goods in this economy $(F)$ are produced by aggregating over a continuum of intermediate home goods indexed by $i \in[0,1]$ along with aggregating over a continuum of imported foreign goods indexed by $\mathrm{j} \in[0,1]$. The ag- 
gregation technology for producing final goods is:

$$
\begin{aligned}
F_{t} & =\left[a^{\frac{1}{\mu}} F_{H, t}^{\frac{\mu-1}{\mu}}+(1-a)^{\frac{1}{\mu}} F_{F, t}^{\frac{\mu-1}{\mu}}\right]^{\frac{\mu}{\mu-1}} \text {, where } \\
F_{H, t} & =\left(\int_{0}^{1} f_{H, t}(i)^{\frac{\lambda-1}{\lambda}} d i\right)^{\frac{\lambda}{\lambda-1}} \\
F_{F, t} & =\left(\int_{0}^{1} f_{F, t}(j)^{\frac{\lambda-1}{\lambda}} d j\right)^{\frac{\lambda}{\lambda-1}} .
\end{aligned}
$$

Here $F_{H}$ represents an aggregate of the home goods sold in the home country, and $F_{F}$ is an aggregate of the imported foreign goods, where lower case counterparts represent outputs of the individual firms.

Final goods producers behave competitively, maximizing profit each period:

$$
\pi_{t}=\max \left[P_{t} F_{t}-P_{H, t} F_{H, t}-P_{F, t} F_{F, t}\right]
$$

where $P$ is the overall price index of the final good, $P_{H}$ is the price index of home goods, and $P_{F}$ is the price index of foreign goods, all denominated in the home currency. These may be defined:

$$
\begin{aligned}
P_{t} & =\left(a P_{H, t}^{1-\mu}+(1-a) P_{F, t}^{1-\mu}\right)^{\frac{1}{1-\mu}} \text { where } \\
P_{H, t} & =\left(\int_{0}^{1} p_{H, t}(i)^{1-\lambda} d i\right)^{\frac{1}{1-\lambda}} \\
P_{F, t} & =\left(\int_{0}^{1} p_{F, t}(j)^{1-\lambda} d j\right)^{\frac{1}{1-\lambda}},
\end{aligned}
$$

and where lower case counterparts again represent the prices set by individual firms.

Given the aggregation functions above, demand will be allocated between home and foreign goods according to

$$
\begin{aligned}
F_{H, t} & =a\left(\frac{P_{H, t}}{P_{t}}\right)^{-\mu} F_{t} \\
F_{F, t} & =(1-a)\left(\frac{P_{F, t}}{P_{t}}\right)^{-\mu} F_{t}
\end{aligned}
$$


with demands for individual goods:

$$
\begin{aligned}
& f_{H, t}(i)=\left(\frac{P_{H, t}(i)}{P_{H, t}}\right)^{-\lambda} F_{H t} \\
& f_{F, t}(j)=\left(\frac{P_{F, t}(j)}{P_{F, t}}\right)^{-\lambda} F_{F t}
\end{aligned}
$$

Analogous conditions apply to the foreign country.

\subsection{Home household problem}

The household derives utility from consumption $(C)$, and supplying labor $(H)$ lowers utility. For simplicity, real money balances $\left(\frac{M_{t}}{P_{t}}\right)$ are also introduced in the utility function, where $P_{t}$ is the overall price level. The household discounts future utility at the rate of time preference $\beta$. Preferences are additively separable in these three arguments.

Households derive income by selling their labor $(H)$ at the nominal wage rate $(W)$, renting out capital to firms at the real rental rate $(r)$, receiving real profits from home firms $(\Pi)$, and from government transfers $(T)$. In addition to money, households can hold two types of noncontingent nominal bonds, one denominated in home currency $\left(B_{H}\right)$ which pays an interest rate $(i)$, and the other denominated in foreign currency $\left(B_{F}\right)$ which pays an interest rate $\left(i^{*}\right)$. The household determines capital accumulation $(K)$, which involves a quadratic adjustment cost that depends upon the parameter $\psi_{I}$ and a constant rate of depreciation $(\delta)$.

The household optimization problem may be written:

$$
\max E_{0} \sum_{t=0}^{\infty} \beta^{t} U\left(C_{t}, \frac{M_{t}}{P_{t}}, H_{t}\right)
$$

subject to the budget constraint:

$$
\begin{aligned}
& P_{t} C_{t}+P_{t}\left(K_{t+1}-(1-\delta) K_{t}\right)+A C_{I, t}+A C_{B, t}+M_{t}+B_{H, t}+S_{t} B_{F, t} \\
= & \left(1+i_{t-1}\right) B_{H, t-1}+S_{t} B_{F, t-1}\left(1+i_{t-1}^{*}\right)+M_{t-1}+W_{t} H_{t}+P_{t} r_{t} K_{t}+T_{t}+\Pi_{t}
\end{aligned}
$$

where

$$
U_{t}=\frac{C_{t}^{1-\rho}}{1-\rho}+\frac{1}{1-\varepsilon}\left(\frac{M_{t}}{P_{t}}\right)^{1-\varepsilon}-\frac{H_{t}^{1+\psi}}{1+\psi}
$$


and

$$
\begin{gathered}
A C_{I, t}=\frac{\psi_{I}}{2} \frac{\left(K_{t+1}-K_{t}\right)^{2}}{K_{t}} \\
A C_{B, t}=\frac{1}{2} \frac{\psi_{B}\left(\left(B_{F, t}-\overline{B_{F}}\right) S_{t}\right)^{2}}{P_{H, t} Y_{t}}
\end{gathered}
$$

The adjustment cost can be rationalized as the cost associated with undertaking positions in assets that are not home-currency denominated. This adjustment cost is introduced to eliminate a unit root in the first-order solution and ensures a stationary equilibrium, which is necessary for computing second moments.

Optimization implies a money demand equation:

$$
\frac{M_{t}}{P_{t}}=\frac{C_{t}^{\rho / \varepsilon}}{\left(1-d_{t}\right)^{1 / \varepsilon}}
$$

a trade-off between consumption and leisure:

$$
\frac{W_{t}}{P_{t} C_{t}^{\rho}}=H_{t}^{\psi}
$$

and a consumption Euler equation:

$$
d_{t}=\beta E_{t} \frac{P_{t} C_{t}^{\rho}}{P_{t+1} C_{t+1}^{\rho}}
$$

with the definition of $d$ :

$$
i_{t}=\frac{1}{d_{t}}-1
$$

an interest parity condition:

$E_{t}\left[\omega_{t} \frac{P_{t} C_{t}^{\rho}}{P_{t+1} C_{t+1}^{\rho}} \frac{S_{t+1}}{S_{t}}\left(1+i_{t}^{*}\right)\left(1+\frac{\psi_{B} S_{t}\left(B_{F, t}-\overline{\left.B_{F}\right)}\right.}{P_{H, t} Y_{t}}\right)^{-1}\right]=E_{t}\left[\frac{P_{t} C_{t}^{\rho}}{P_{t+1} C_{t+1}^{\rho}}\left(1+i_{t}\right)\right]$

and finally, capital accumulation is set to equate the costs and expected costs:

$$
\frac{1}{\beta}\left(1+\psi_{I} \frac{K_{t+1}-K_{t}}{K_{t}}\right)=E_{t}\left[\frac{C_{t}^{\rho}}{C_{t+1}^{\rho}}\left(r_{t+1}+1-\delta+\frac{1}{2} \psi_{I} \frac{K_{t+2}^{2}-K_{t+1}^{2}}{K_{t+1}^{2}}\right)\right]
$$

The cost, on the left side,is the gross return if the funds instead had been used to purchase bonds; and the benefits on the right include the return 
from the rental capital plus the resale value after depreciation, and the fact that a larger capital stock lowers the expected adjustment cost of further accumulation in the subsequent period.

Note that the presence of adjustment costs to bonds accumulation and second-order terms leads to a violation of the UIP condition. However, disregarding the adjustment cost that are very small, a log-linear approximation of equation (19) will yield $i_{t}-i_{t}^{*}=E_{t}\left(s_{t+1}-s_{t}\right)$. It has been well documented (Lewis [1995]) that this UIP condition is strongly rejected by the data. That is why we augment (19) by a mean-one disturbance $\omega_{t}$ that tries to capture time-varying deviations from the UIP. Other models that use the same device include McCallum and Nelson [1999], Kollmann [2002a and 2002b] and Jeanne and Rose [2002]. The foreign country's UIP condition is similar. The UIP shock plays a key role in the model since it is the theoretical counterpart of the exchange rate shock identified later in the GARCH-SVAR exercise. While there are authors (see Choudri, Faruqee and Hakura [2003]) that assume that these shocks are the same, we should be careful to recognize that truly identified empirical UIP shocks depend on the particular assumption about the nature of expectations formation. We will more cautiously refer to the shocks from the GARCH-SVAR and the theoretical model as non-fundamental shocks originating in the exchange rate market.

\subsection{Home firm problem}

Firms set prices in their own currency, both for sale domestically and sale abroad. That is, we assume producer currency pricing in that the price charged to the foreign consumers is just the optimal price for the home market multiplied by the relevant exchange rate. They rent capital $(K)$ at the rental rate $r$, and hire labor $(H)$ at the nominal rate $W$. It is assumed that it is costly to reset prices because of quadratic menu costs ${ }^{7}$. The home firm maximization problem is:

$$
\max E_{0} \sum_{t=0}^{\infty} \rho_{t, t+n} \Pi_{H, t}(i)
$$

where

\footnotetext{
${ }^{7}$ It has been demonstrated in Rotemberg (1982) that menu costs of this type, although simple to specify and work with, generate price dynamics identical to those of Calvo random price staggering
} 


$$
\Pi_{H, t(i)}=\left(P_{H, t}(i)-M C_{t}(i)-A C_{P, t}(i)\right) f_{H, t}(i),
$$

with the adjustment and marginal costs defined respectively as:

$$
\begin{gathered}
A C_{P, t}(i)=\frac{\psi_{P}}{2} \frac{\left(p_{H, t}(i)-p_{H, t-1}(i)\right)^{2}}{p_{H, t-1}(i)}, \\
M C_{t}=\frac{\left(r_{t} P_{t}\right)^{\alpha} W_{t}^{1-\alpha}}{\theta_{t} \alpha^{\alpha}(1-\alpha)^{1-\alpha}}
\end{gathered}
$$

and subject to the demand function for $f_{H, t}(i)$ from above and the production function.

$$
f_{H, t}(i)+f_{H, t}^{*}(i)=\theta_{t} K_{t}^{\alpha}(i) H_{t}^{1-\alpha}(i)=Y_{t}(i)
$$

Here $\theta$ represents technology common to all production firms in the country. Lastly, $\rho_{t, t+n}$ is the pricing kernel used to value random date $t+n$ payoffs. Since firms are assumed to to be owned by the representative household, it is also assumed that firms value future profits according to the household's intertemporal marginal rate of substitution in consumption, so $\rho_{t, t+n}=\beta^{n}\left(U_{C, t+n}^{\prime} / P_{t+n}\right) /\left(U_{C, t}^{\prime} / P_{t}\right)$, where $U_{C, t+n}^{\prime}$ is the household's marginal utility of consumption in period $t+n$. The optimization problem implies a trade-off between capital and labor inputs that depend on the relative cost of each:

$$
P_{t} r_{t} K_{t}(i)=\frac{\alpha}{1-\alpha} W_{t} H_{t}(i)
$$

and price setting behavior:

$$
\begin{aligned}
& \frac{1}{2} \psi_{P} E_{t}\left[\frac{\rho_{t, t+i+1}}{\rho_{t, t+i}}\left(\frac{p_{H, t+1}^{2}}{p_{H, t}^{2}}-1\right) \frac{F_{H, t+1}}{F_{H t}}\right]-\psi_{P}\left(\frac{p_{H, t}}{p_{H, t-1}}-1\right)+ \\
& +\lambda\left(\frac{M C_{t}}{p_{H, t}}+\frac{\psi_{P}}{2} \frac{\left(p_{H, t}-p_{H, t-1}\right)^{2}}{p_{H, t} p_{H, t-1}}-1\right)+1=0
\end{aligned}
$$

Then the optimal price for the foreign market will be $p_{H, t}^{*}=p_{H, t} / S_{t}$.

\subsection{Government}

To facilitate comparison with earlier literature (Obstfeld and Rogoff [2001], Devereux and Engel [2000] and Bachetta and Van Wincoop[2000]), we follow them in using a money growth rule:

$$
m_{t}=m_{t-1}+a_{s} \frac{s_{t}}{\bar{s}}
$$


where lower case letters represent logs of upper case counterparts. For the conducted experiments the parameter $a_{s}$ will be set to a value near but not zero, which will allow considerable exchange rate variability but will rule out a random walk in the exchange rate. :

The government's budget constraint is:

$$
T_{t}=\frac{1}{P_{t}}\left(M_{t}-M_{t-1}\right)
$$

\subsection{Market clearing}

Market clearing for the home goods market requires:

$$
F_{H, t}+F_{H, t}^{*}=Y_{t}
$$

and for the home bond market:

$$
B_{H, t}+B_{H, t}^{*}=0 .
$$

Total home demand $(F)$ may be defined:

$$
F_{t}=C_{t}+\left(K_{t+1}-(1-\delta) K_{t}\right)+A C_{I, t}+A C_{B, t}+\int_{0}^{1} A C_{P, t}(i) d i
$$

The home balance of payments condition may be written:

$$
\begin{aligned}
& B_{H, t}-\frac{B_{H, t}}{d_{t-1}}+S_{t}\left[B_{F, t}-\frac{B_{F, t}}{d_{t-1}^{*}}\right]-P_{H, t} Y_{t}+ \\
& P_{t} C_{t}+P_{t}\left(K_{t+1}-(1-\delta) K_{t}\right)=0
\end{aligned}
$$

Similar conditions apply to the foreign country. The shocks, to technology and UIP, will be log-normally distributed:

$$
\begin{aligned}
\left(\log \theta_{t}-\log \bar{\theta}\right) & =\rho_{1}\left(\log \theta_{t-1}-\log \bar{\theta}\right)+\varepsilon_{1, t} \\
\left(\log \theta_{t}^{*}-\log \overline{\theta^{*}}\right) & =\rho_{1}^{*}\left(\log \theta_{t-1}^{*}-\log \overline{\theta^{*}}\right)+\varepsilon_{1, t}^{*} \\
\left(\log \omega_{t}-\log \bar{\omega}\right) & =\rho_{2}\left(\log \omega_{t-1}-\log \bar{\omega}\right)+\varepsilon_{2, t}
\end{aligned}
$$

To deal with the nonstationary nominal variables in this system, they will be transformed by dividing by their respective national price levels. As noted above, this does not need to be done for the nominal exchange rate. 


\subsection{Computation of the welfare measure}

A second-order Taylor expansion of the utility function yields:

$$
E U^{8}{ }_{t}=\bar{U}+\bar{C}^{1-\rho} E\left(\hat{C}_{t}\right)-\frac{1}{2} \rho \bar{C}^{1-\rho} \operatorname{var}\left(\hat{C}_{t}\right)-\bar{H}^{1+\psi} E\left(\widehat{H}_{t}\right)-\frac{1}{2} \psi \bar{H}^{1+\psi} \operatorname{var}\left(\hat{H}_{t}\right) .
$$

In computing the welfare implications from the shocks we follow Lucas [1987] in that we represent them as the permanent shift in steady state consumption required to achieve the same expected utility, i.e. we find how much steady state consumption the household is ready to give up in order to negate the effect of the shocks. Since we use a second-order approximation, however, we can go even further. We can separate the effects of a particular shock to the dynamic system. The shock matters because it influences the expected levels of the variables and because it has a bearing on the their second moments. While the latter can be found relatively easy from a first-order solution, the former can be gleaned only from a full second-order expansion of the model. Let $u^{\text {mean }}$ denote the permanent shift in steady state consumption that delivers the same expected utility. Then making use of (37) we must have that

$$
U\left(\left(1+u^{\text {mean }}\right) C, H\right)=\frac{\left(\left(1+u^{\text {mean }}\right) \bar{C}\right)^{1-\rho}}{1-\rho}-\frac{\bar{H}^{1+\psi}}{1+\psi}=\bar{U}+\bar{C}^{1-\rho} E\left(\hat{C}_{t}\right)-\bar{H}^{1+\psi} E\left(\hat{H}_{t}\right) .
$$

Solving for $u^{\text {mean }}$ we get:

$$
u^{\text {mean }}=\left[1+(1-\rho) E\left(\hat{C}_{t}\right)-\frac{(1-\rho) \bar{H}^{1+\psi}}{\bar{C}^{1-\rho}} E\left(\hat{H}_{t}\right)\right]^{\frac{1}{1-\rho}}-1 .
$$

\footnotetext{
${ }^{8}$ J. Kim, S. Kim, Schaumburg and Sims (2003) argue that in principle it is advisable to use a conditional welfare criterion if it is the case that the transition from one steady state to another takes a long time. J. Kim and S. Kim (2003) provide an example where for certain parameter values the unconditional welfare under autarky is higher than the one with complete markets. This does not happen when the conditonal welfare is used. In our exercise, however, this might not be a problem since we are not comparing alternative policies and/or providing sensitivity analysis based on different parameter values. In the same time since the empirical part is concerned with the conditional mean effects of exchange rate risk, it seems desirable to analyze the conditional effects of exchange rate uncertainty in the theoretical counterpart as well. This will be a topic for future investigation.
} 
In a similar fashion we derive $u^{\text {var }}$ which denotes the permanent shift in steady state consumption associated with the effect of the shocks on the variances of the variables. We find that:

$U\left(\left(1+u^{v a r}\right) C, H\right)=\frac{\left(\left(1+u^{\operatorname{var}}\right) \bar{C}\right)^{1-\rho}}{1-\rho}-\frac{\bar{H}^{1+\psi}}{1+\psi}=-\rho \bar{C}^{1-\rho} \operatorname{var}\left(\hat{C}_{t}\right)-\psi \bar{H}^{1+\psi} \operatorname{var}\left(\hat{H}_{t}\right)$.

Thus $u^{v a r}$ can be found:

$$
u^{v a r}=\left[1-\frac{1}{2} \rho(1-\rho) \operatorname{var}\left(\hat{C}_{t}\right)-\frac{1}{2} \psi \frac{(1-\rho) \bar{H}^{1+\psi}}{\bar{C}^{1-\rho}} \operatorname{var}\left(\hat{H}_{t}\right)\right]^{\frac{1}{1-\rho}}-1
$$

The values for $u^{\text {mean }}$ and $u^{v a r}$ reported in Table 2 are coming from these calculations.

\subsection{Calibration}

In the benchmark case of the model we choose the following parameterization. The elasticity of substitution between home and foreign goods $\mu$ is a critical parameter in our experiments. According to some studies, such as Harrigan [1993] and Trefler and Lai [1999], a sensible assumption for this parameter is 5 . Rotemberg and Woodford [1998] set the degree of monopolistic competition $\lambda$ to be 7.66 which implies an average price mark-up of $15 \%$. We choose $\lambda=7$. The share of home goods in he home final goods aggregator, $a$, is set to 0.80 , reflecting the $20 \%$ share of imports in GDP for the G7 countries in the 1990:1-1998:4 period.

The interest elasticity of real money balances is $(1 / \epsilon)$. Empirical studies find a wide range of estimates: from 0.39 in Chari at al.[1998] to 0.05 in Mankiw and Summers [1986]. We choose an intermediate value of $0.25(\epsilon=$ 4). Empirical studies estimate the income elasticity of real money demand $(\rho / \epsilon)$ to be about unity, so we also set $\rho=4$. This happens to be in the range of the estimates for the coefficient of relative risk aversion provided by Hall [1988] (as low as 1 and as high as 33) and also by Gali, Gertler and Lopez-Salido [2002] who suggest a value between 3 and 10 .

The specification of the utility function has the convenient feature that the household has a well-defined static labor supply function, whose elasticity, $1 / \psi$, is constant. The value for this elasticity is controversial. Microeconomic studies (for example, Killingsworth and Heckman [1986]) suggest 
values between 0.5-1.5. We follow Christiano at. al. [1997] and set $\psi=1$. A unitary labor supply elasticity is consistent with the fact that per-capita labor supply has changed little while real wages have risen in recent decades. We calibrate $\beta=0.99$ and interpret a period in the model as one quarter. For the depreciation rate we choose $\delta=0.025$, and for the capital share in production $\alpha=0.36$.

The price adjustment cost is set at $\psi_{P}=50$, which implies that $95 \%$ of the price has adjusted 4 periods after a monetary shock. Investment adjustment cost, $\psi_{I}=5$, is calibrated such that investment is about three times more volatile than output. Bond adjustment cost, $\psi_{B}=0.000004$, is necessary in order to negate the unit root associated with the incompleteness of the asset markets. We need the monetary policy reaction parameter $a_{s}=1 x 10^{-6}$, in order to eliminate the unit root in the monetary policy rule. It is crucial that the first-order solution does not contain unit roots, because, otherwise, the variances of the variables will grow to infinity.

The variance and the persistence of the technology shock is calibrated at standard values: $\operatorname{var}\left(\varepsilon_{1}\right)=\operatorname{var}\left(\varepsilon_{1}^{*}\right)=.01^{2}$ and $\rho_{1}=\rho_{1}^{*}=0.90$, similar to values in RBC studies such as Backus, Kehoe and Kydland [1992] and identical to (Kollmann [2002]). The UIP shock is calibrated following Kollmann [2002], i.e. $\operatorname{var}\left(\varepsilon_{2}\right)=0.033$ and $\rho_{2}=0.5$.

\section{Results}

Table 3 reports the results from our benchmark calibration, showing the effect of uncertainty on welfare. In particular, it reports the unconditional mean of utility in the second-order approximation of the model minus that of the certainty-equivalent version of the model. To aid interpretation, this difference in utilities is presented in terms of the change in the steady state level of consumption that would be needed to change utility the same amount. As is usual in this literature, utility is computed as a function of consumption and leisure, abstracting from the effects of holdings of real money balances.

\subsection{Benchmark case}

The benchmark case may be viewed as a more fully fleshed out version of the model used in the theoretical analysis of exchange rate by Obstfeld and Rogoff [2001], where the model here has been extended to include investment, 
multiperiod price stickiness, and more realistic calibration of some parameters like the elasticity of substitution between home and foreign goods and the money demand elasticity.

The welfare effects are quite small, amounting to a fall in utility equal to $0.087 \%$ of steady state consumption. A useful comparison is the results of Lucas [1987], which measured the effect of volatility arising from business cycle fluctuations. He found that for risk aversion coefficient of 5 , the loss of welfare was equivalent to a loss in average consumption of 0.042 percent and concluded that this was a trivial magnitude.

The results from the breakdown of the shocks reveal interesting results. The UIP shocks bring about significant variability in consumption, output and investment. The variability of the nominal exchange rate is about 4 times lower than the one coming from the data. While the UIP shocks have been introduced in most theoretical contributions with the clear purpose of explaining the excess volatility of exchange rate movements, our quantitative results do not seem to support this notion. In support of Kollmann [2002], the UIP shocks generate considerable volatility in real variables, but in contrast to him much less impressive volatility of the nominal exchange rate. This may not be unexpected as Bergin [2002], for example, finds that the portion of exchange rate variability that is due to the UIP shocks is around $1 \%$. Traditionally, shocks originating from the money market have been found to be more important in matching empirical exchange rate variability.

We also find that the mean levels of consumption and output increase following UIP shocks. While work effort is also higher, the mean welfare is actually rising. This result might stand in contradiction to our general belief that variability of shocks in the exchange rate market should hurt consumers by making them consume and produce less. Note, however, that there are theoretical models in which increases in exchange rate risk could potentially lead to higher trade (Bachetta and van Wincoop [2000]), so that the presence of UIP shocks may not be expected a priori to lead to lower mean welfare. In our model higher exchange rate volatility induces consumers to save and invest more, which leads to a higher level of production and consumption, lower prices and less aggressive monetary policy. This is consistent with our empirical results. It is worth mentioning, however, that a significant advantage of our methodology is the ability to break down the effect of welfare into mean and variance effect. While mean welfare is positive, the overall welfare is lower because the UIP shock brings about an increase in the variability of consumption and labor. The main reason why in our model, 
relative to the one in Obstfeld and Rogoff [2001], the levels of output and consumption rise, is the possibility to accumulate capital. As in our model second moments and uncertainty have a direct effect on the levels of variables, savings and capital accumulation provide an additional channel to generate an increase of the expected future income (due to precautionary motives). Since capital accumulation is positively influenced by uncertainty (see Table 3 and 4), potential output is higher and, therefore, via general equilibrium effects, consumption increases as well.

\subsection{Habit persistence}

Bergin and Tchakarov [2003] have shown that adopting a specification with habit persistence gives rise to big welfare effects in a similar model with technology and money demand shocks. We explore this possibility here as well. In particular, we consider the utility function:

$$
U_{t}=\frac{\left(C_{t}-\gamma C_{t-1}\right)^{1-\rho}}{1-\rho}+\frac{1}{1-\epsilon}\left(\frac{M_{t}}{P_{t}}\right)^{1-\epsilon}-\frac{H_{t}^{1+\psi}}{1+\psi}
$$

As $\gamma$ goes to unity, households act to smooth changes in consumption rather than the level of consumption. Habit persistence has been extensively used to explain financial anomalities such as the equity premium puzzle, and has been advocated in the macroeconomic literature as a way of better capturing consumer behavior. One might expect risk to have larger welfare effects here, as consumers dislike large and rapid changes in consumption, and so they are more sensitive to consumption risk than agents with time-separable utility function. We calibrate the habit persistence parameter at $\gamma=0.8$.which is approximately what Deaton [1987] and Constantinides [1990] require to explain aggregate consumption smoothness and the equity premium puzzle.

The results from table 4 show that welfare losses are very big. Overall welfare decreases by almost $4 \%$. The UIP shocks lead to considerable loss in the portion of welfare that is due only to the variability of consumption and labor $(-2.2687 \%)$. The mean levels of consumption and output are higher but agents work much less which leads to a higher mean welfare as in the benchmark case. Somewhat surprisingly, the mean levels of model variables change very little due to risk here. Nevertheless the welfare of households falls significantly, both because of the changes in variance and means, when 
measured in terms of steady state consumption. This may be explained by the fact that under habit persistence, households do not care much about steady state levels of consumption but rather about changes in consumption between periods, so that a large amount of steady state consumption must be used to compensate for lost welfare. These results are again borne out by the empirical exercise.

The latter fact is very important as it underscores that even very small mean changes in the variables might generate big welfare results.

\section{Conclusion}

In this paper we provide some empirical and theoretical evidence about the effect of non-fundamental exchange rate volatility on welfare. On the empirical front, given a shock that causes revisions in volatility, we show that non-fundamental exchange rate volatility has small effect on the conditional value of the variables. However, in the theoretical part of the paper we show that conditional on the model set up even small effects of non-fundamental volatility can have large effects on welfare.

There are several issues that have not been addressed in the present analysis. First of all, notice that there is no one to one match between the empirical and the theoretical model. The stochastic steady state is the unconditional expected mean of the variable, while the IRFs in the empirical exercise represent the change of the conditional mean. Therefore it might be interesting to calculate the IRF of the model given the second order approximation of the equilibrium conditions in order to establish a closer connection between the two parts. However, this is, although not impossible, a very cumbersome exercise.

The empirical and quantitative results provide a bridge to other contributions that analyze the effect of exogenous volatility of monetary policy on the level of economic activity ${ }^{9}$. These papers have been primarily concerned with closed economies. As has been emphasized by Rogoff [2003], it is the volatility of interest rates that is more likely to be important for economic activity in the G-3 countries rather than exchange rate uncertainty. In this sense, an exercise that tries to directly compare the effects of exchange rate

\footnotetext{
${ }^{9}$ See for example Jorda and Salyer [2003], Dotsey and Sarte [2000] and Dupor [2003].
} 
versus interest rate risk in an open-economy GARCH-SVAR might be interesting. Furthermore, Reinhart and Reinhart [2002] argue that G-3 interest rate volatility hurts developing countries far more than exchange rate volatility. This claim can also be evaluated within the empirical framework used in this paper.

\section{References}

[1] Artis, M. and M. Ehrmann, 2000," The Exchange Rate - A ShockAbsorber or Source of Shocks? A Study of Four Open Economies" CEPR Working Paper 2550.

[2] Bacchetta, P. and E. van Wincoop, 2000, "Does Exchange Rate Stability Increase Trade and Welfare?" American Economic Review 90.

[3] Backus, D., P. Kehoe and F. Kydland, 1992, "International Real Business Cycles", Journal of Political Economy, Vol. 100, No. 4.

[4] Baxter, M. and A. Stockman, 1989, "Business cycles and the exchange rate regime: Some International Evidence" Journal of Monetary Economics, vol 23 (3).

[5] Bergin, P., 2002, "How Well Can the New Open Economy Macroeconomics Explain the Exchange Rate and Current Account?", mimeo., UC Davis.

[6] Bergin, P. and I.Tchakarov, 2003, "Does Exchange Rate Risk Matter for Welfare? A Quantitative Investigation", NBER Working Paper No. 9900 .

[7] Chari, V.V., Patrick Kehoe and Ellen McGrattan, 1998,"Can Sticky Price Models Generate Volatile and Persistent Real Exchange Rates?," Staff Report 223, Federal Reserve Bank of Minneapolis, December.

[8] Choudhri, E. Hamid Faruqee and Dalia S. Hakura, 2003, "Explaining the Exchange Rate Pass-Through in Different Prices", IMF.

[9] Christiano, L. J., Martin Eichenbaum and Charles Evans, 1997, "Sticky Price and Limited Participation Models of Money: A Comparison," European Economic Review, No. 41, 1021-1049. 
[10] Christiano, L. J., Martin Eichenbaum and Charles Evans, 1999, "Monetary Policy Shocks: What Have We Learned and to What End?", mimeo., Northwestern University

[11] Constantinides, G. M, 1990, "Habit Formation: A Resolution of the Equity Premium Puzzle", Journal of Political Economy 98.

[12] Corsetti, G. and P. Pesenti, 2001, "Welfare and Macroeconomic Interdependence", Quarterly Journal of Economics 116(2), 401-426

[13] Cushman, D. and T. Zha, 1997, "Identifying Monetary Policy in a Small Open Economy under Flexible Exchange Rates," Journal of Monetary Economics 39.

[14] Deaton, A., 1987, "Life-cycle Models of Consumption: Is the Evidence Consistent with the Theory?", in Advances in Econometrics Fifth World Congress, Vol. 2, ed. by T. Bewley, Cambridge University Press.

[15] Devereux, M. and C. Engel, 2000, "Monetary Policy in the Open Economy Revisited: Price Setting and Exchange Rate Flexibility," Working Paper no. 7665, National Bureau of Economic Research.

[16] Dotsey, M. and P. Sarte, 2000, "Inflation Uncertainty and Growth in a Cash-in-Advance Economy", Journal of Monetary Economics 45.

[17] Dupor, B., 2003, "Optimal Random Monetary Policy with Nominal Rigidity", forthcoming in Journal of Economic Theory.

[18] Eichenbaum, M. and C. Evans, 1995, "Some Empirical Evidence on the Effects of Monetary Policy Shocks on Exchange Rates", Quarterly Journal of Economics,110(4).

[19] Frankel, Jeffrey A. and Shang Jin Wei, (1993) "Trading Blocs and Currency Blocs," NBER Working Paper No. 4335.

[20] Friedman, M., 1953, "The Case for Flexible Exchange Rates," in: Essays in Positive Economics, University of Chicago.

[21] Gali, Jordi, Mark Gertler and J. David Lopez-Salido, 2002 "Markups, Gaps, and the Welfare Costs of Business Fluctuations.", NBER Working paper No:8850. 
[22] Grilli, V. and N. Roubini, 1996, "Liquidity Models in the Open Economy: Theory and Empirical Evidence", European Economic Review, April 1996.

[23] Goldberg, Linda and Michael Klein,1998, "Foreign Direct Investment, Trade and Real Exchange Rate Linkages in Developing Countries", in Managing Capital Flows and Exchange Rates: Perspectives from the Pacific Basin, edited by Reuven Glick. (Cambridge University Press).

[24] Hall, Robert, 1988, "Intertemporal Substitution in Consumption," Journal of Political Economy, vol. 96, no. 2, 339-357.

[25] Hamilton, James D.,1994, "Time Series Analysis", Princeton University Press.

[26] Harrigan, J., 1993, "OECD Imports and Trade Barriers in 1983," Journal of International Economics, 35, 91-111.

[27] Jeanne, O. and A. Rose, 2002, "Noise Trading and Exchange Rate Regimes", Quarterly Journal of Economics $11 \%$.

[28] Jorda, O. and K. Salyer, 2003, "'The Response of Term Rates to Monetary Policy Uncertainty", Review of Economic Dynamics, forthcoming.

[29] Killingsworth, M. and Heckman, J., 1986, "Female Labor Supply: A Survey", in O. Ashenfelter and R. Layard, (eds.), Handbook of Labor Economics, Handbook in Economic Series, No. 5, Vol. 1, 103-204.

[30] Kim, S., 2001, "International transmission of U.S. monetary policy shocks: Evidence from VAR's", Journal of Monetary Economics, Volume 48 , Issue 2 .

[31] Kim, S. and N. Roubini, 2000, "Exchange Rate Anomalies in the Industrial Countries: A Solution with a Structural VAR Approach", Journal of Monetary Economics, Volume 45, Issue 3.

[32] Kim, J. and S. Kim, 2003, "Spurious Welfare Reversals in International Business Cycle Models," Journal of International Economics, 60.

[33] Kim , J. , S. Kim, E. Schaumburg and C. Sims, 2003, "Calculating and Using Second Order Accurate Solutions of Discrete Time Dynamic Equilibrium Models," mimeo. Princeton University. 
[34] Lewis, K., 1995, "Puzzles in International Financial Markets", in: G. Grossman and K. Rogoff, eds., Handbook of International Economics, Vol. III (Elsevier, Amsterdam).

[35] Lucas, R. E., 1987, Models of Business Cycles, Basil Blackwell, New York.

[36] Kollmann, R., 2002a, "Monetary Policy Rules in the Open Economy: Effects on Welfare and Business Cycles," Journal of Monetary Economics 49 .

[37] Kollmann, R., 2002b, "Monetary Policy Rules in an Interdependent World", mimeo., University of Bonn.

[38] McCallum, B. and E. Nelson, 1999, "Nominal Income Targeting in an Open-Economy Optimizing Model", Journal of Monetary Economics 43.

[39] Mankiw, N. Gregory and Lawrence H. Summers, 1986, "Money demand and the effects of Fiscal Policies," Journal of Money, Credit and Banking 18, 415-29.

[40] Obstfeld, M. and K. Rogoff, 2001, "Risk and Exchange Rates," NBER Working Paper \#6694.

[41] Reinhart, C. and V. Reinhart, 2002, "What Hurts the Most? G-3 Exchange Rate or Interest Rate Variability", in Preventing Currency Crises in Emerging Markets, ed. by S. Edwards and J. Frenkel, Chicago: University of Chicago Press and the NBER.

[42] Rogoff, K., 2003, "A Vote Against Grandiose Schemes", Finance and Development, vol 40, quarterly publication of the IMF.

[43] Rotemberg, J, 1982, "Sticky Prices in the United States", Journal of Political Economy, vol 90, No 6 1187-1211.

[44] Rotemberg, J and Michael Woodford, 1998, "An Optimization-Based Econometric Framework for the Evaluation of Monetary Policy," in B.S. Bernanke and Rotemberg (eds.), NBER Macroeconomic Annual 1997, Cambridge, MA, MIT Press, 297-346.

[45] Sims, C., J.H. Stock and M. Watson, 1990, "Inference in Linear Time Series Models with Some Unit Roots", Econometrica 58. 
[46] Smets, F., 2001, "Measuring Monetary Policy Shocks in France, Germany and Italy: the Role of the Exchange Rate", http://www.eabcn.org/research/authors/smets_frank.htm.

[47] Trefler, D., and H. Lai, 1999, "The Gains from Trade: Standard Errors with the CES Monopolistic Competition Model," unpublished manuscript, University of Toronto.

[48] Woodford, Michael, 2003, "Interest and Prices", Princeton University Press. 


\section{Table 3: Benchmark Case}

Both shocks

\section{$\underline{\text { Standard Deviations: }}$}

$\begin{array}{llll}\mathrm{c} & 1.5217 & 0.8744 & 1.2028 \\ \mathrm{y} & 1.9725 & 1.3271 & 1.4639 \\ \mathrm{I} & 7.0601 & 4.8911 & 4.9319 \\ \mathrm{~s} & 2.2543 & 1.7942 & 1.3036\end{array}$

$\underline{\text { Stochastic steady state deviations }}{ }^{1}$ : $\underline{\text { UIP shocks }}$

$\underline{\text { Technology shocks }}$ i

i*

$\mathrm{u}$

$\mathrm{u}^{*}$$$
\mathrm{c}
$$

$\mathrm{c}^{*}$

0.0357

$\mathrm{h}$

0.0357

0.0377

$\mathrm{h}^{*}$

0.0377

0.1341

$\mathrm{y}$

0.1341

$\mathrm{y}^{*}$

$\mathrm{k}$

0.5665

$\mathrm{k}^{*}$

0.5665

$-0.1072$

$-0.1072$

$-0.1139$

$-0.1139$

0.0210

0.0210

0.0057

0.0057

0.1012

0.1012

0.4534

0.4534

$-0.0967$

$-0.0967$

$-0.0054$

$-0.0054$

$-0.0206$

$-0.0671$

u-variance

$-0.0877$

u-mean

0.0079

u-mean*

0.0079

$-0.0798$

u-all

u-all*

$-0.0798$
0.0168

$-0.0090$

0.0168

$-0.0090$

$-0.0038$

$-0.0760$

$-0.0038$
0.0146

0.0146

0.0320

0.0320

0.0516

0.0516

0.1131

0.1131

$-0.0105$

$-0.0105$

$-0.1085$

$-0.1085$

${ }^{1}$ Percent difference between stochastic steady state and deterministic steady state.

${ }^{2}$ Difference between stochastic steady state and deterministic steady state shown as a share of deterministic steady state consumption.

Notation is as follows: c represents consumption, $\mathrm{h}$ labor, $\mathrm{y}$ production, I investment, $\mathrm{i}$ nominal interest rate, $\mathrm{s}$ nominal exchange rate, $\mathrm{k}$ capital stock, $\mathrm{u}$ utility. Stars represent foreign variables. 


\section{Table 4: Habit persistence}

$\underline{\text { Both shocks }} \quad \underline{\text { UIP shocks }} \quad \underline{\text { Technology shocks }}$

\section{Standard Deviations:}

$\begin{array}{llll}\mathrm{c} & 1.1724 & 1.0782 & 1.1537 \\ \mathrm{y} & 1.6415 & 1.4160 & 1.2615 \\ \mathrm{I} & 4.8987 & 2.9023 & 3.9464 \\ \mathrm{~s} & 2.0290 & 1.9459 & 0.5748\end{array}$

Stochastic steady state deviations ${ }^{1}$ :

$\begin{array}{llll}\text { c } & -0.0005 & 0.0029 & -0.0034 \\ \text { c* }^{*} & -0.0005 & 0.0029 & -0.0034 \\ \mathrm{~h} & 0.0091 & -0.0154 & 0.0245 \\ \mathrm{~h}^{*} & 0.0091 & -0.0154 & 0.0245 \\ \mathrm{y} & 0.0518 & 0.0391 & 0.0127 \\ \mathrm{y}^{*} & 0.0518 & 0.0391 & 0.0127 \\ \mathrm{k} & 0.3451 & 0.2420 & 0.1031 \\ \mathrm{k}^{*} & 0.3451 & 0.2420 & 0.1031 \\ \mathrm{i} & -0.0615 & -0.0437 & -0.0178 \\ \mathrm{i}^{*} & -0.0615 & -0.0437 & -0.0178 \\ \mathrm{u} & -0.0777 & -0.0221 & -0.0556 \\ \mathrm{u}^{*} & -0.0777 & -0.0221 & -0.0556\end{array}$

As percentage of steady state consumption ${ }^{2}$ :

$\begin{array}{llll}\text { u-variance } & -3.5122 & -2.2687 & -1.3606 \\ \text { u-mean } & -0.5317 & 0.9326 & -1.4120 \\ \text { u-mean* } & -0.5317 & 0.9326 & -1.4120 \\ \text { u-all } & -3.9735 & -1.4190 & -2.6988 \\ \text { u-all* } & -3.9735 & -1.4190 & -2.6988\end{array}$

\footnotetext{
${ }^{1}$ Percent difference between stochastic steady state and deterministic steady state.

${ }^{2}$ Difference between stochastic steady state and deterministic steady state shown as a share of deterministic steady state consumption.

Notation is as follows: $\mathrm{c}$ represents consumption, $\mathrm{h}$ labor, y production, I investment, i nominal interest rate, $\mathrm{s}$ nominal exchange rate, $\mathrm{k}$ capital stock, $\mathrm{u}$ utility. Stars represent foreign variables.
} 


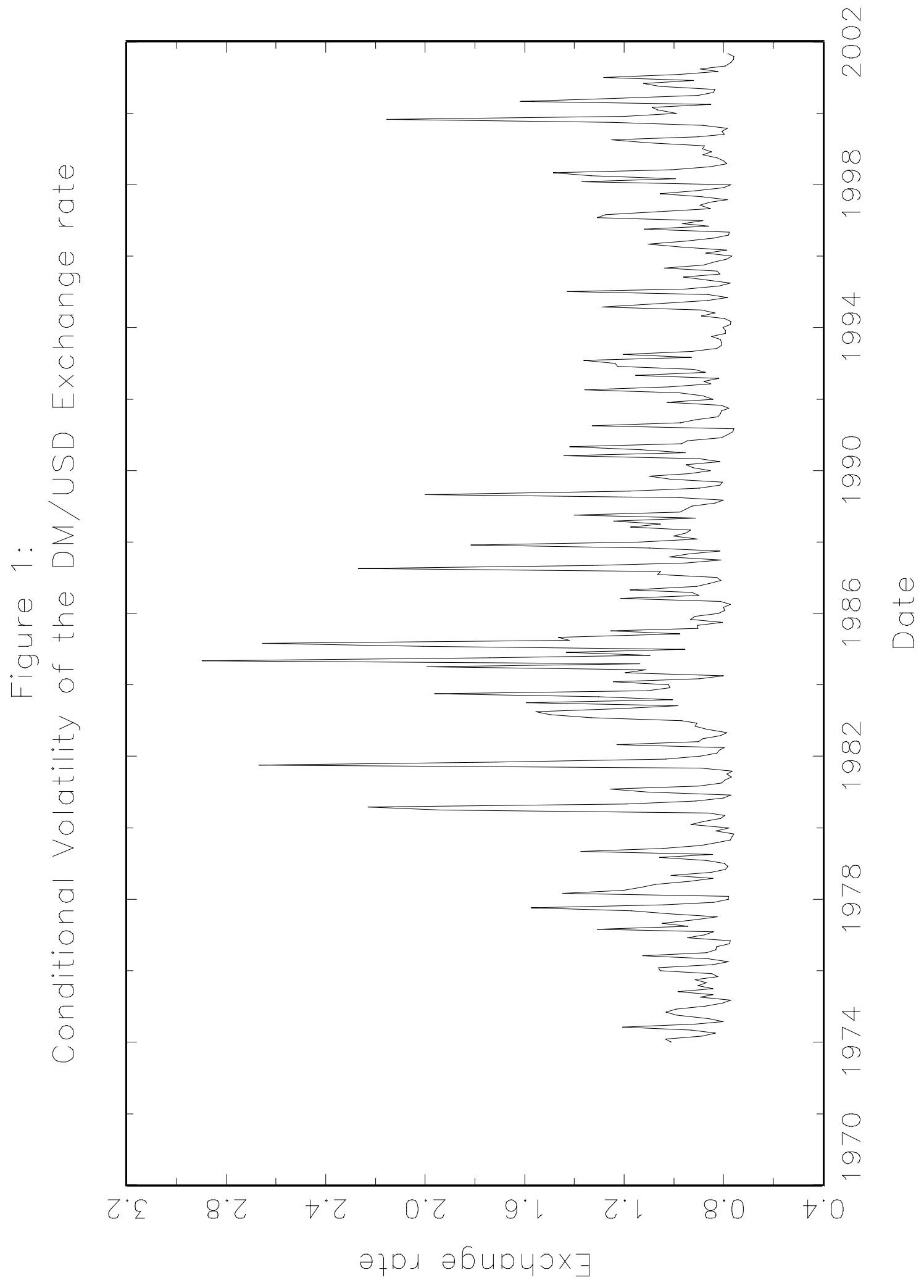



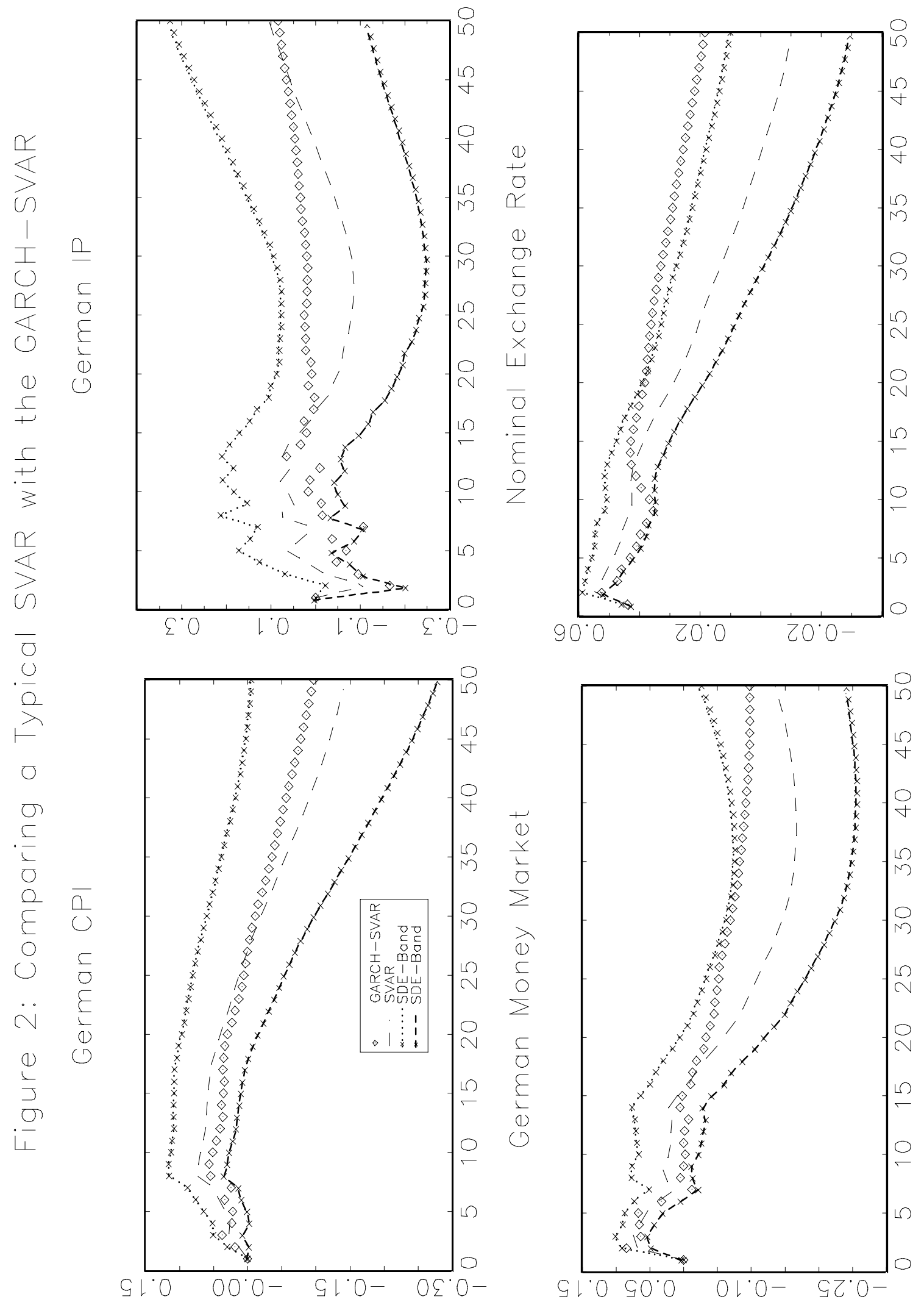

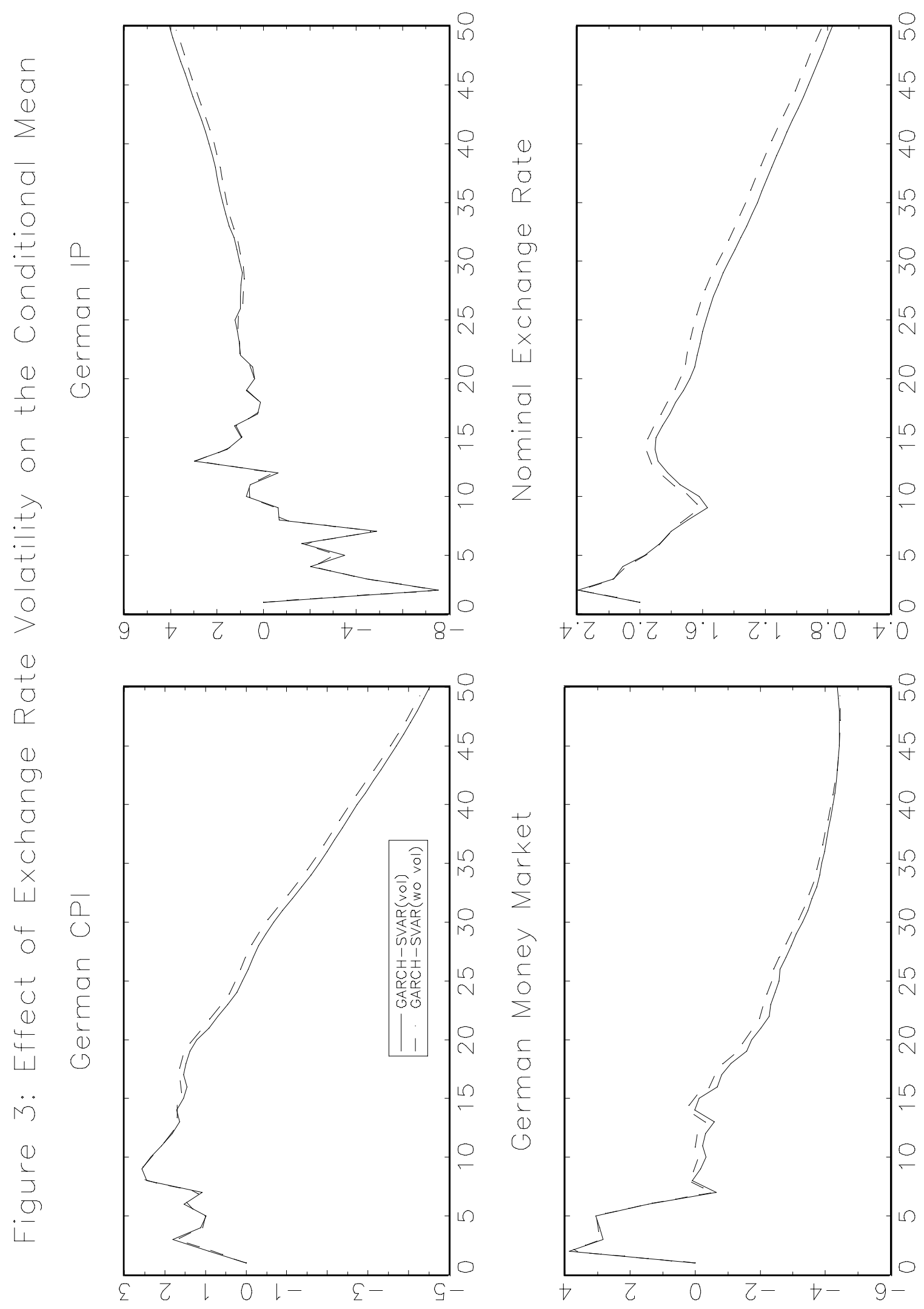


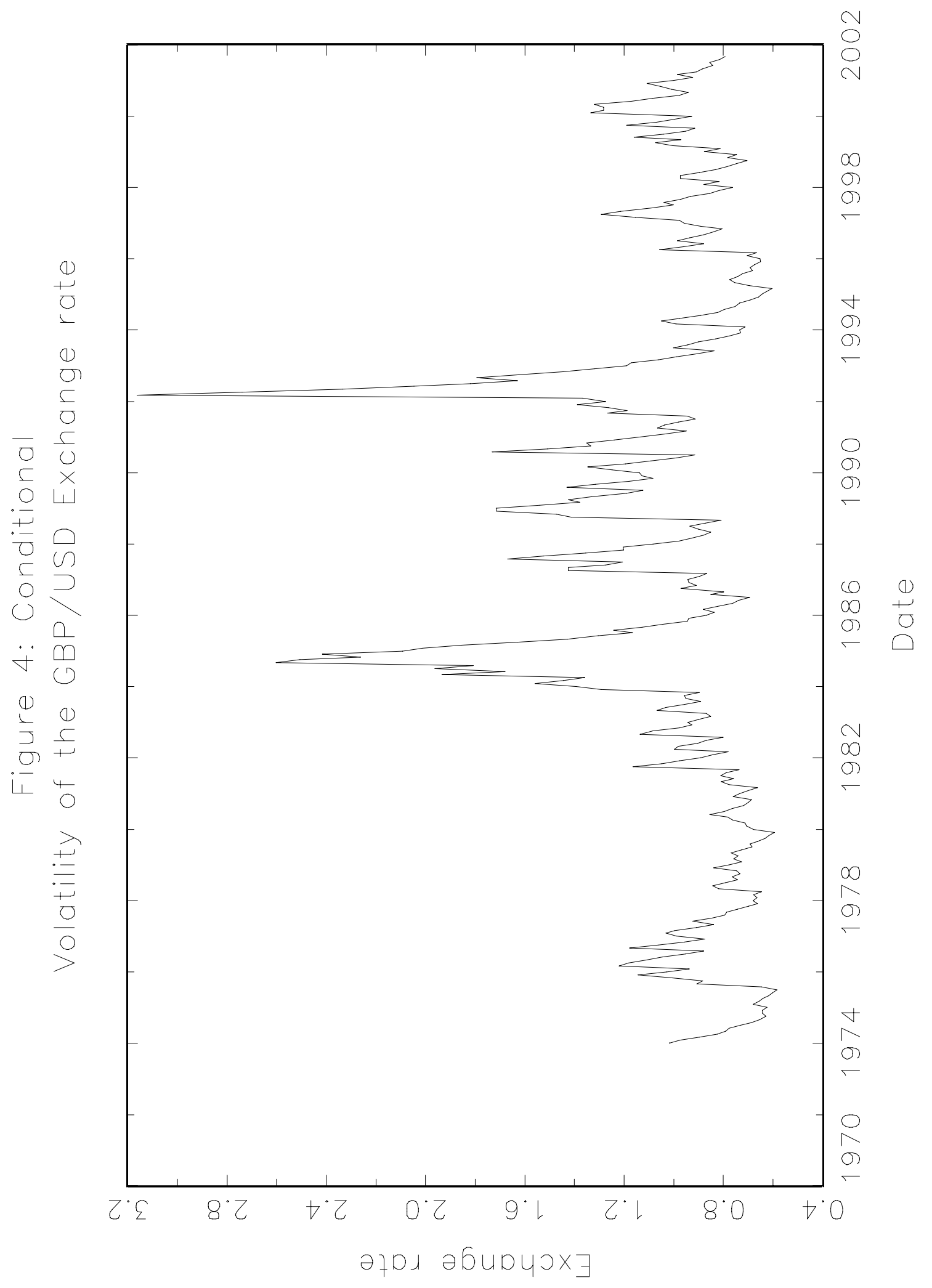



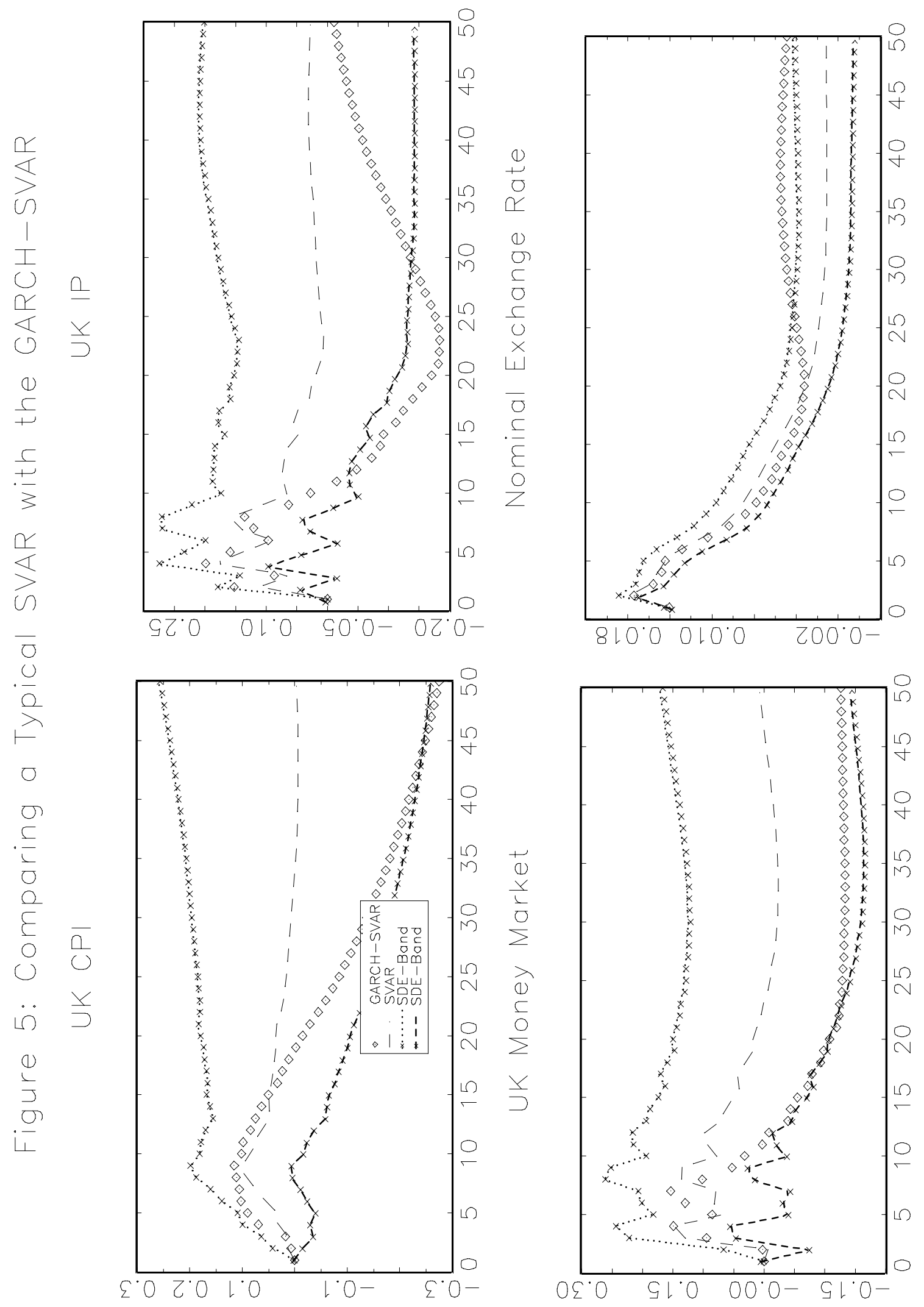


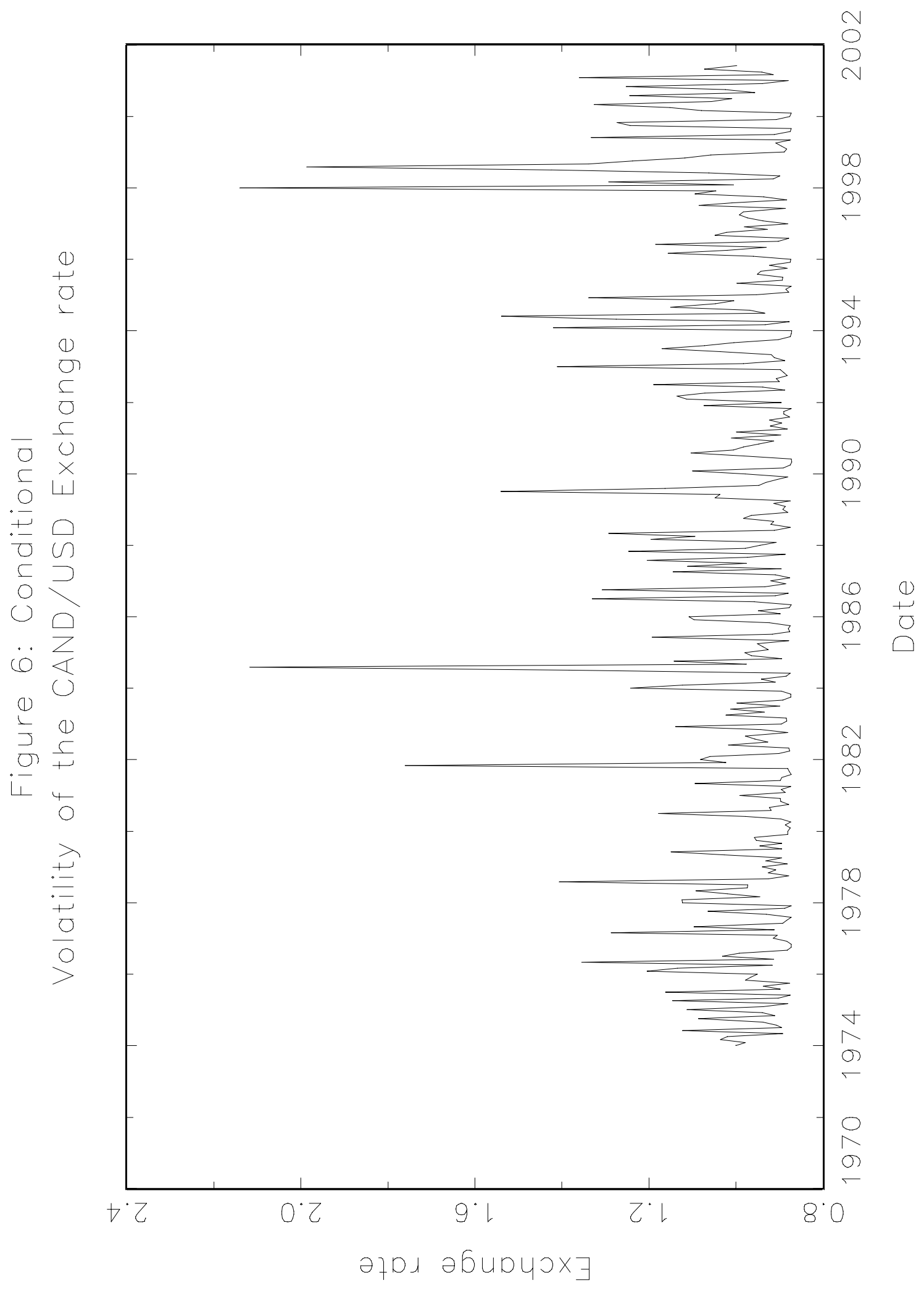



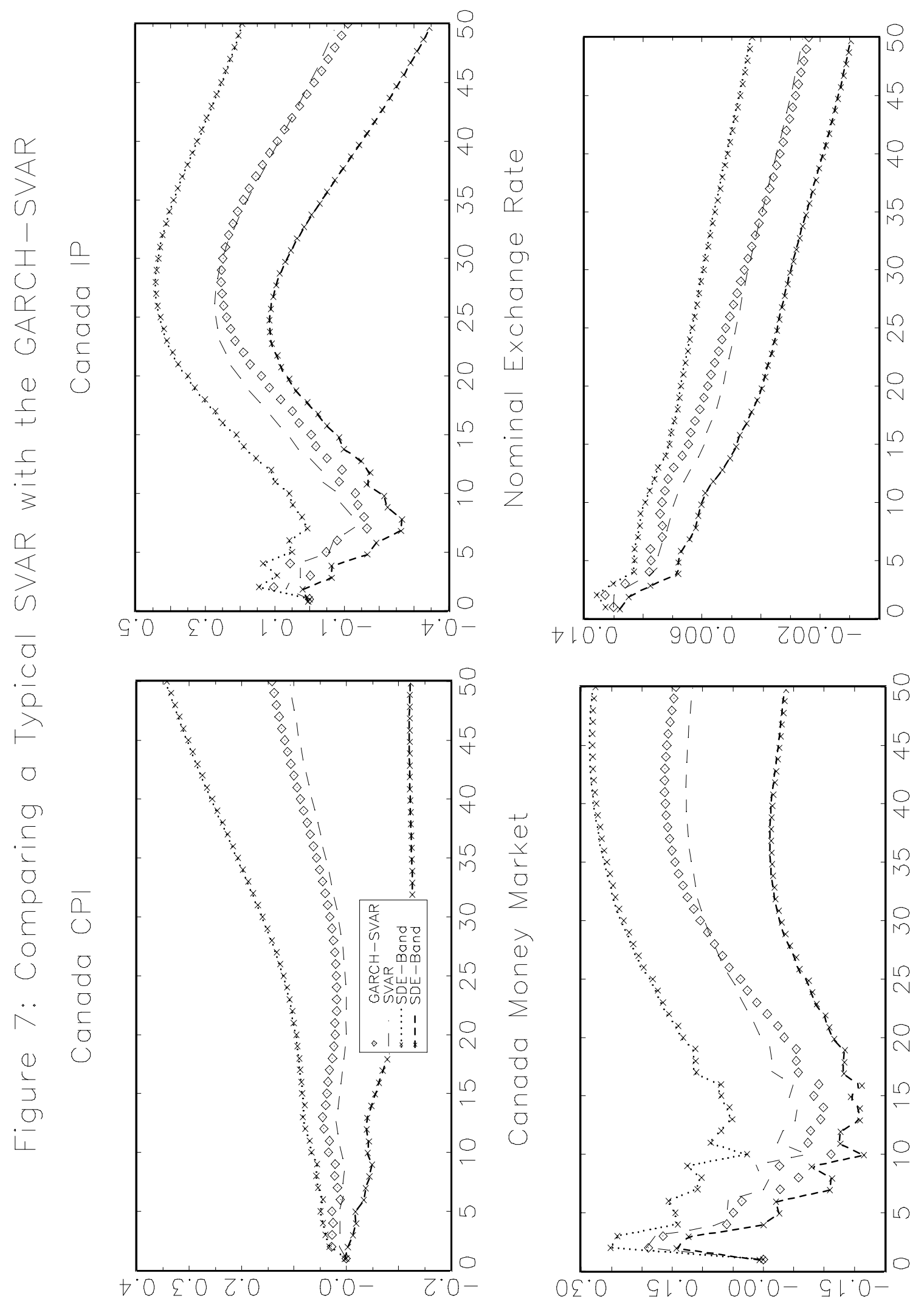


\section{European Central Bank working paper series}

For a complete list of Working Papers published by the ECB, please visit the ECB's website (http://www.ecb.int).

202 "Aggregate loans to the euro area private sector" by A. Calza, M. Manrique and J. Sousa, January 2003.

203 "Myopic loss aversion, disappointment aversion and the equity premium puzzle" by D. Fielding and L. Stracca, January 2003.

204 "Asymmetric dynamics in the correlations of global equity and bond returns" by L. Cappiello, R.F. Engle and K. Sheppard, January 2003.

205 "Real exchange rate in an inter-temporal n-country-model with incomplete markets" by B. Mercereau, January 2003.

206 "Empirical estimates of reaction functions for the euro area" by D. Gerdesmeier and B. Roffia, January 2003.

207 “A comprehensive model on the euro overnight rate” by F. R. Würtz, January 2003.

208 "Do demographic changes affect risk premiums? Evidence from international data" by A. Ang and A. Maddaloni, January 2003.

209 “A framework for collateral risk control determination” by D. Cossin, Z. Huang, D. Aunon-Nerin and F. González, January 2003.

210 "Anticipated Ramsey reforms and the uniform taxation principle: the role of international financial markets” by S. Schmitt-Grohé and M. Uribe, January 2003.

211 "Self-control and savings" by P. Michel and J.P. Vidal, January 2003.

212 "Modelling the implied probability of stock market movements" by E. Glatzer and M. Scheicher, January 2003.

213 “Aggregation and euro area Phillips curves” by S. Fabiani and J. Morgan, February 2003.

2I4 "On the selection of forecasting models" by A. Inoue and L. Kilian, February 2003.

215 "Budget institutions and fiscal performance in Central and Eastern European countries" by H. Gleich, February 2003.

216 "The admission of accession countries to an enlarged monetary union: a tentative assessment” by M. Ca'Zorzi and R. A. De Santis, February 2003.

217 "The role of product market regulations in the process of structural change" by J. Messina, March 2003. 
218 "The zero-interest-rate bound and the role of the exchange rate for monetary policy in Japan" by G. Coenen and V. Wieland, March 2003.

219 "Extra-euro area manufacturing import prices and exchange rate pass-through" by B. Anderton, March 2003.

220 "The allocation of competencies in an international union: a positive analysis" by M. Ruta, April 2003.

221 "Estimating risk premia in money market rates" by A. Durré, S. Evjen and R. Pilegaard, April 2003.

222 "Inflation dynamics and subjective expectations in the United States" by K. Adam and M. Padula, April 2003.

223 "Optimal monetary policy with imperfect common knowledge" by K. Adam, April 2003.

224 "The rise of the yen vis-à-vis the ("synthetic") euro: is it supported by economic fundamentals?" by C. Osbat, R. Rüffer and B. Schnatz, April 2003.

225 "Productivity and the ("synthetic") euro-dollar exchange rate" by C. Osbat, F. Vijselaar and B. Schnatz, April 2003.

226 "The central banker as a risk manager: quantifying and forecasting inflation risks" by L. Kilian and S. Manganelli, April 2003.

227 "Monetary policy in a low pass-through environment" by T. Monacelli, April 2003.

228 "Monetary policy shocks - a nonfundamental look at the data" by M. Klaeffing, May 2003.

229 "How does the ECB target inflation?" by P. Surico, May 2003.

230 "The euro area financial system: structure, integration and policy initiatives" by P. Hartmann, A. Maddaloni and S. Manganelli, May 2003.

231 "Price stability and monetary policy effectiveness when nominal interest rates are bounded at zero" by G. Coenen, A. Orphanides and V. Wieland, May 2003.

232 "Describing the Fed's conduct with Taylor rules: is interest rate smoothing important?" by E. Castelnuovo, May 2003.

233 "The natural real rate of interest in the euro area" by N. Giammarioli and N. Valla, May 2003.

234 "Unemployment, hysteresis and transition" by M. León-Ledesma and P. McAdam, May 2003.

235 "Volatility of interest rates in the euro area: evidence from high frequency data" by N. Cassola and C. Morana, June 2003. 
236 "Swiss monetary targeting 1974-1996: the role of internal policy analysis" by G. Rich, June 2003.

237 "Growth expectations, capital flows and international risk sharing" by O. Castrén, M. Miller and R. Stiegert, June 2003.

238 "The impact of monetary union on trade prices" by R. Anderton, R. E. Baldwin and D. Taglioni, June 2003.

239 "Temporary shocks and unavoidable transitions to a high-unemployment regime" by W. J. Denhaan, June 2003.

240 "Monetary policy transmission in the euro area: any changes after EMU?" by I. Angeloni and M. Ehrmann, July 2003.

24I Maintaining price stability under free-floating: a fearless way out of the corner?" by C. Detken and V. Gaspar, July 2003.

242 "Public sector efficiency: an international comparison" by A. Afonso, L. Schuknecht and V. Tanzi, July 2003.

243 "Pass-through of external shocks to euro area inflation" by E. Hahn, July 2003.

244 "How does the ECB allot liquidity in its weekly main refinancing operations? A look at the empirical evidence” by S. Ejerskov, C. Martin Moss and L. Stracca, July 2003.

245 "Money and payments: a modern perspective" by C. Holthausen and C. Monnet, July 2003.

246 "Public finances and long-term growth in Europe - evidence from a panel data analysis" by D. R. de Ávila Torrijos and R. Strauch, July 2003.

247 "Forecasting euro area inflation: does aggregating forecasts by HICP component improve forecast accuracy?" by K. Hubrich, August 2003.

248 "Exchange rates and fundamentals" by C. Engel and K. D. West, August 2003.

249 "Trade advantages and specialisation dynamics in acceding countries" by A. Zaghini, August 2003.

250 "Persistence, the transmission mechanism and robust monetary policy" by I. Angeloni, G. Coenen and F. Smets, August 2003.

25I "Consumption, habit persistence, imperfect information and the lifetime budget constraint" by A. Willman, August 2003.

252 "Interpolation and backdating with a large information set" by E. Angelini, J. Henry and M. Marcellino, August 2003.

253 "Bond market inflation expectations and longer-term trends in broad monetary growth and inflation in industrial countries, I880-200I” by W. G. Dewald, September 2003. 
254 "Forecasting real GDP: what role for narrow money?" by C. Brand, H.-E. Reimers and F. Seitz, September 2003.

255 "Is the demand for euro area M3 stable?" by A. Bruggeman, P. Donati and A. Warne, September 2003.

256 "Information acquisition and decision making in committees: a survey" by K. Gerling, H. P. Grüner, A. Kiel and E. Schulte, September 2003.

257 “Macroeconomic modelling of monetary policy” by M. Klaeffling, September 2003.

258 "Interest rate reaction functions and the Taylor rule in the euro area" by P. GerlachKristen, September 2003.

259 "Implicit tax co-ordination under repeated policy interactions" by M. Catenaro and J.-P. Vidal, September 2003.

260 "Aggregation-theoretic monetary aggregation over the euro area, when countries are heterogeneous" by W. A. Barnett, September 2003.

261 "Why has broad money demand been more stable in the euro area than in other economies? A literature review" by A. Calza and J. Sousa, September 2003.

262 "Indeterminacy of rational expectations equilibria in sequential financial markets" by P. Donati, September 2003.

263 "Measuring contagion with a Bayesian, time-varying coefficient model" by M. Ciccarelli and A. Rebucci, September 2003.

264 "A monthly monetary model with banking intermediation for the euro area" by A. Bruggeman and M. Donnay, September 2003.

265 "New Keynesian Phillips Curves: a reassessment using euro area data" by P. McAdam and A. Willman, September 2003.

266 "Finance and growth in the EU: new evidence from the liberalisation and harmonisation of the banking industry" by D. Romero de Ávila, September 2003.

267 "Comparing economic dynamics in the EU and CEE accession countries" by R. Süppel, September 2003.

268 "The output composition puzzle: a difference in the monetary transmission mechanism in the euro area and the US" by I. Angeloni, A. K. Kashyap, B. Mojon and D. Terlizzese, September 2003.

269 "Zero lower bound: is it a problem with the euro area?" by G. Coenen, September 2003.

270 "Downward nominal wage rigidity and the long-run Phillips curve: simulation-based evidence for the euro area" by G. Coenen, September 2003.

27I "Indeterminacy and search theory" by N. Giammarioli, September 2003. 
272 "Inflation targets and the liquidity trap" by M. Klaeffling and V. López Pérez, September 2003.

273 "Definition of price stability, range and point inflation targets: the anchoring of long-term inflation expectations" by E. Castelnuovo, S. Nicoletti-Altimari and D. RodriguezPalenzuela, September 2003.

274 "Interpreting implied risk neutral densities: the role of risk premia" by P. Hördahl and D. Vestin, September 2003.

275 "Identifying the monetary transmission mechanism using structural breaks" by A. Beyer and R. Farmer, September 2003.

276 "Short-term estimates of euro area real GDP by means of monthly data" by G. Rünstler, September 2003.

277 "On the indeterminacy of determinacy and indeterminacy" by A. Beyer and R. Farmer, September 2003.

278 "Relevant economic issues concerning the optimal rate of inflation" by D. R. Palenzuela, G. Camba-Méndez and J. Á. García, September 2003.

279 "Designing targeting rules for international monetary policy cooperation" by G. Benigno and P. Benigno, October 2003.

280 “Inflation, factor substitution and growth” by R. Klump, October 2003.

$28 \mathrm{I}$ "Identifying fiscal shocks and policy regimes in OECD countries" by G. de Arcangelis and S. Lamartina, October 2003.

282 "Optimal dynamic risk sharing when enforcement is a decision variable" by T. V. Koeppl, October 2003.

283 "US, Japan and the euro area: comparing business-cycle features” by P. McAdam, November 2003.

284 “The credibility of the monetary policy 'free lunch"” by J. Yetman, November 2003.

285 "Government deficits, wealth effects and the price level in an optimizing model" by B. Annicchiarico, November 2003.

286 "Country and sector-specific spillover effects in the euro area, the United States and Japan" by B. Kaltenhaeuser, November 2003.

287 “Consumer inflation expectations in Poland” by T. Łyziak, November 2003.

288 "Implementing optimal control cointegrated I(I) structural VAR models" by F. V. Monti, November 2003.

289 "Monetary and fiscal interactions in open economies" by G. Lombardo and A. Sutherland, November 2003. 
290 "Inflation persistence and robust monetary policy design" by G. Coenen, November 2003.

291 "Measuring the time-inconsitency of US monetary policy" by P. Surico, November 2003.

292 "Bank mergers, competition and liquidity" by E. Carletti, P. Hartmann and G. Spagnolo, November 2003.

293 “Committees and special interests” by M. Felgenhauer and H. P. Grüner, November 2003.

294 “Does the yield spread predict recessions in the euro area?" by F. Moneta, December 2003.

295 "Optimal allotment policy in the eurosystem's main refinancing operations?" by C. Ewerhart, N. Cassola, S. EjerskoV and N. Valla, December 2003.

296 "Monetary policy analysis in a small open economy using bayesian cointegrated structural VARs?" by M. Villani and A. Warne, December 2003.

297 “Measurement of contagion in banks' equity prices” by R. Gropp and G. Moerman, December 2003.

298 "The lender of last resort: a 2 I st century approach" by X. Freixas, B. M. Parigi and J.-C. Rochet, December 2003.

299 "Import prices and pricing-to-market effects in the euro area” by T. Warmedinger, January 2004.

300 "Developing statistical indicators of the integration of the euro area banking system" by M. Manna, January 2004.

301 “Inflation and relative price asymmetry” by A. Rátfai, January 2004.

302 “Deposit insurance, moral hazard and market monitoring” by R. Gropp and J. Vesala, February 2004.

303 "Fiscal policy events and interest rate swap spreads: evidence from the EU" by A. Afonso and R. Strauch, February 2004.

304 "Equilibrium unemployment, job flows and inflation dynamics" by A. Trigari, February 2004.

305 "A structural common factor approach to core inflation estimation and forecasting" by C. Morana, February 2004.

306 "A markup model of inflation for the euro area" by C. Bowdler and E. S. Jansen, February 2004.

307 "Budgetary forecasts in Europe - the track record of stability and convergence programmes" by R. Strauch, M. Hallerberg and J. von Hagen, February 2004.

308 "International risk-sharing and the transmission of productivity shocks" by G. Corsetti, L. Dedola and S. Leduc, February 2004.

309 "Monetary policy shocks in the euro area and global liquidity spillovers" by J. Sousa and A. Zaghini, February 2004.

310 "International equity flows and returns: A quantitative equilibrium approach" by R. Albuquerque, G. H. Bauer and M. Schneider, February 2004.

311 "Current account dynamics in OECD and EU acceding countries - an intertemporal approach" by M. Bussière, M. Fratzscher and G. Müller, February 2004. 
312 "Similarities and convergence in G-7 cycles" by F. Canova, M. Ciccarelli and E. Ortega, February 2004.

313 "The high-yield segment of the corporate bond market: a diffusion modelling approach for the United States, the United Kingdom and the euro area" by G. de Bondt and D. Marqués, February 2004.

314 "Exchange rate risks and asset prices in a small open economy" by A. Derviz, March 2004.

315 "Option-implied asymmetries in bond market expectations around monetary policy actions of the ECB" by S. Vähämaa, March 2004.

316 "Cooperation in international banking supervision" by C. Holthausen and T. Rønde, March 2004.

317 "Fiscal policy and inflation volatility" by P. C. Rother, March 2004.

318 "Gross job flows and institutions in Europe" by R. Gómez-Salvador, J. Messina and G. Vallanti, March 2004.

319 "Risk sharing through financial markets with endogenous enforcement of trades" by T. V. Köppl, March 2004.

320 "Institutions and service employment: a panel study for OECD countries" by J. Messina, March 2004.

321 "Frequency domain principal components estimation of fractionally cointegrated processes" by C. Morana, March 2004.

322 "Modelling inflation in the euro area" by E. S. Jansen, March 2004.

323 "On the indeterminacy of New-Keynesian economics" by A. Beyer and R. E. A. Farmer, March 2004.

324 "Fundamentals and joint currency crises" by P. Hartmann, S. Straetmans and C. G. de Vries, March 2004.

325 "What are the spill-overs from fiscal shocks in Europe? An empirical analysis" by M. Giuliodori and R. Beetsma, March 2004.

326 "The great depression and the Friedman-Schwart hypothesis" by L. Christiano, R. Motto and M. Rostagno, March 2004.

327 "Diversification in euro area stock markets: country versus industry" by G. A. Moerman, April 2004.

328 "Non-fundamental exchange rate volatility and welfare" by R. Straub and I. Tchakarov, April 2004. 
